Trinity University

Digital Commons @ Trinity

7-15-2021

\title{
Months-Long Spike in Aqueous Arsenic Following Domestic Well Installation and Disinfection: Short- and Long-Term Drinking Water Quality Implications
}

\author{
M. L. Erickson \\ E. D. Swanner \\ Brady A. Ziegler \\ Trinity University, bziegler@trinity.edu \\ J. R. Havig
}

Follow this and additional works at: https://digitalcommons.trinity.edu/geo_faculty

Part of the Earth Sciences Commons

\section{Repository Citation}

Erickson, M. L., Swanner, E. D., Ziegler, B. A., \& Havig, J. R. (2021). Months-long spike in aqueous arsenic following domestic well installation and disinfection: Short- and long-term drinking water quality implications. Journal of Hazardous Materials, 414 Article 125409. http://doi.org/10.1016/ j.jhazmat.2021.125409

This Article is brought to you for free and open access by the Geosciences Department at Digital Commons @ Trinity. It has been accepted for inclusion in Geosciences Faculty Research by an authorized administrator of Digital Commons@ Trinity. For more information, please contact jcostanz@trinity.edu. 


\title{
Months-long spike in aqueous arsenic following domestic well installation and disinfection: Short- and long-term drinking water quality implications
}

\author{
Melinda L. Erickson ${ }^{\text {a, }}$, Elizabeth D. Swanner ${ }^{\mathrm{b}}$, Brady A. Ziegler ${ }^{\mathrm{c}}$, Jeff R. Havig ${ }^{\mathrm{d}}$ \\ ${ }^{a}$ US Geological Survey, 2280 Woodale Drive, Mounds View, MN 55112, United States \\ ${ }^{\mathrm{b}}$ Department of Geological \& Atmospheric Sciences, Iowa State University, 253 Science, Ames, IA 50011, United States \\ ${ }^{\mathrm{c}}$ Department of Geosciences, Trinity University, One Trinity Place, \#45, San Antonio, TX 78212, United States \\ ${ }^{\mathrm{d}}$ Department of Earth and Environmental Sciences, University of Minnesota, 116 Church Street SE., Minneapolis, MN 55455, United States
}

\section{A R T I C L E I N F O}

\section{Keywords:}

Arsenic

Geogenic contamination

Redox geochemistry

Geochemical disequilibrium

Well disinfection

Domestic well

\begin{abstract}
A B S T R A C T
Exposure to high concentration geogenic arsenic via groundwater is a worldwide health concern. Well installation introduces oxic drilling fluids and hypochlorite (a strong oxidant) for disinfection, thus inducing geochemical disequilibrium. Well installation causes changes in geochemistry lasting $12+$ months, as illustrated in a recent study of 250 new domestic wells in Minnesota, north-central United States. One study well had extremely high initial arsenic $(1550 \mu \mathrm{g} / \mathrm{L})$ that substantially decreased after 15 months $(5.2 \mu \mathrm{g} / \mathrm{L})$. The drilling and development of the study well were typical and ordinary; nothing observable indicated the very high initial arsenic concentration. We hypothesized that oxidation of arsenic-containing sulfides (which lowers $\mathrm{pH}$ ) combined with low $\mathrm{pH}$ dissolution of arsenic-bearing Fe (oxyhydr)oxides caused the very high arsenic concentration. Geochemical equilibrium considerations and modeling supported our hypothesis. Groundwater equilibrium redox conditions are poised at the $\mathrm{Fe}(\mathrm{III})_{(\mathrm{s})} / \mathrm{Fe}(\mathrm{II})_{(\mathrm{aq})}$ stability boundary, indicating arsenic-bearing $\mathrm{Fe}$ (oxyhydr) oxide mineral sensitivity to $\mathrm{pH}$ and redox changes. Changing groundwater geochemistry can have negative implications for home water treatment (e.g., reduced arsenic removal efficiency, iron fouling), which can lead to ongoing but unrecognized hazard of arsenic exposure from domestic well water. Our results may inform arsenic mobilization processes and geochemical sensitivity in similarly complex aquifers in Southeast Asia and elsewhere.
\end{abstract}

\section{Introduction}

Geogenic arsenic (As) can adversely affect groundwater quality in geologically diverse aquifers in North and South America, Africa, Europe, and Southeast Asia (Bonsor et al., 2017; Bundschuh et al., 2012; McArthur et al., 2016; Ravenscroft et al., 2013; Shakoor et al., 2015; Smedley and Kinniburgh, 2002). Arsenic in aquifer sediments is often associated with iron (Fe) and sulfur (S) minerals, primarily Fe (oxyhydr) oxides and Fe sulfides. Fe (oxyhydr)oxides are thermodynamically favored under oxidizing conditions and circumneutral $\mathrm{pH}$; Fe sulfides, such as arsenopyrite, FeAsS, and As-rich pyrite, $\mathrm{FeS}_{2-\mathrm{x}} \mathrm{As}_{\mathrm{x}}$, are thermodynamically favored under reducing conditions (Schreiber and Rimstidt, 2013). Groundwater As contamination can be caused by reduction of Fe (oxyhydr)oxide solids to aqueous Fe and subsequent As desorption, by reductive desorption of As from Fe (oxyhydr)oxide solids, or by oxidation of As-bearing sulfides to aqueous species (Kocar et al.,
2006; Shankar et al., 2014; Smedley and Kinniburgh, 2002; Tufano et al., 2008; Welch et al., 2000). Groundwater As mobilization mechanisms can also be affected by local flow-system changes (Bexfield and Jurgens, 2014; Degnan et al., 2020; Erickson and Barnes, 2006; Gotkowitz et al., 2004; McArthur et al., 2010), seasonal hydrologic changes (Ayotte et al., 2015; Biswas et al., 2014; Degnan et al., 2020), well installation (Erickson et al., 2019b; Wallis and Pichler, 2018), and biofuel or other hydrocarbon spills (Cozzarelli et al., 2016; Ziegler et al., 2015).

Throughout the glacial aquifer system in the northern United States including Minnesota, more than $10 \%$ of the groundwater resource has high As concentrations ( $>10 \mu \mathrm{g} / \mathrm{L}$ ), the U.S. Environmental Protection Agency (USEPA) standard for public water systems and the World Health Organization (WHO) drinking water standard (U.S. Environmental Protection Agency, 2017; World Health Organization, 2017). High As concentrations typically range from 10 to $<100 \mu \mathrm{g} / \mathrm{L}$ (Erickson

\footnotetext{
* Corresponding author.

E-mail addresses: merickso@usgs.gov (M.L. Erickson), eswanner@iastate.edu (E.D. Swanner), bziegler@trinity.edu (B.A. Ziegler), jhavig@umn.edu (J.R. Havig).
} 
et al., 2019a; Minnesota Department of Health, 2017b). Oxidation of As-bearing sulfides has been most commonly associated with high As concentrations in bedrock wells in the northern United States (Ayotte et al., 2003; Erickson et al., 2019b; Schreiber et al., 2000). In contrast, high As in glacial aquifers has been more commonly associated with reducing conditions (Erickson et al., 2019a; Thomas, 2007; Warner and Ayotte, 2014). In Minnesota glacial aquifers, Nicholas et al. (2017), found similar amounts of As in As-bearing sulfides (e.g., arsenopyrite) and $\mathrm{Fe}$ (oxyhydr)oxides in sediments where groundwater conditions were conducive to As release due to oxidative dissolution reactions.

In the upper Midwestern United States, As is prevalent in glacial and bedrock aquifers that lie within the footprint of the Late Pleistocene Des Moines Lobe glacial till, and As is more common in domestic wells than in public-water supply wells (Erickson and Barnes, 2005a, 2005b). The geology of Minnesota is complex, owing to sediment deposition from multiple glaciations (Lusardi, 1997). Late Pleistocene glaciation (approximately 15,000 years before present) deposited a heterogeneous mixture of fine sediment and organic matter that creates geochemical conditions that promote the release of As from those sediments into groundwater (Erickson and Barnes, 2005a; Nicholas et al., 2017). Geochemically reduced (As- and Fe-bearing sulfides) and oxidized (oxidized As and $\mathrm{Fe}$ ) redox end-members are expected to represent conditions that retain solid-phase As phase until the system is perturbed by changes in redox, water chemistry, or hydrologic conditions. But the system is actively weathering, with potential for As release to water as indicated by co-located As sulfide minerals with oxidized Fe (Nicholas et al., 2017). Arsenic mobilization can therefore occur in these glacial sediments, either by reductive dissolution/reductive desorption of $\mathrm{Fe}$ (oxyhydr)oxides or oxidation of As-bearing sulfides. Adsorbed As can be desorbed due to changes in $\mathrm{pH}$, and it can be mobilized by low-pH dissolution of Fe (oxyhydr)oxide solids to aqueous Fe (Cravotta, 2008).

Studies estimate between 80,000 (Ayotte et al., 2017) and 130,000 (Minnesota Department of Health, 2017a) domestic water well users in Minnesota are exposed to drinking water As concentrations above 10 $\mu \mathrm{g} / \mathrm{L}$. For the purpose of this paper, 'high' is defined as $>10 \mu \mathrm{g} / \mathrm{L}$, even though chronic exposure to As at lower concentration can cause adverse health effects (Almberg et al., 2017; Bulka et al., 2016; Monrad et al., 2017).

Well installation can affect groundwater geochemistry due to introduction of oxidizing drilling fluids (oxygenated tap water) into reducing groundwater, chlorination (strong oxidizer) for sanitation, and induction of potential intra-borehole flow. Additionally, the act of using wells for water supply can cause disequilibrium conditions (Gotkowitz et al., 2004; McArthur et al., 2010). The process of well installation can release or sequester As and other metals in wells, depending on the natural As-bearing phase and the changing redox or $\mathrm{pH}$ conditions initiated by installation, for example desorption or mobilization of metals during (oxidative) weathering (Gotkowitz et al., 2008; Wallis and Pichler, 2018). The effect of well installation on measured geochemical conditions in wells can last for a year or more (Erickson et al., 2019b; Wallis and Pichler, 2018).

In Minnesota, domestic well water is required to be sampled for As prior to potable use (State of Minnesota, 2017), but domestic well water is not required to comply with the $10 \mu \mathrm{g} / \mathrm{L}$ standard for public supplies. Although recommended in some circumstance, no regulatory follow-up sampling is required for domestic wells. A recent study of 250 wells looked at sampling protocols at new wells and groundwater geochemical evolution after well installation in three study regions in Minnesota (Erickson et al., 2018, 2019b).

Here we present a detailed geochemical study for one of the new domestic wells that had atypical groundwater geochemistry: the initial As concentration (days to weeks after installation) was a human health hazard. In this study, we describe the hydrogeologic setting, drilling process, and measured geochemistry. We then hypothesize As mobilization/sequestration mechanisms, test our hypotheses with geochemical equilibria modeling, and describe the public health implications of our study results. Finally, we put the groundwater equilibrium results into the regional context of groundwater contamination from geogenic As. Our glacial geologic setting shares some important characteristics to deltaic and other high-As aquifers in Southeast Asia: late Pleistocene/ Holocene age, complex layering of aquifers and confining units, low-As sediment concentrations, and geochemical controls on As mobilization. Our improved understanding the human-induced geochemical changes associated with drilling, installing, sanitizing, pumping, and sampling of drinking water wells can inform guidance in the United States, in areas of Southeast Asia or elsewhere.

\section{Hydrogeologic setting}

The study well is located in the north-central part of the United States, in central Minnesota (Fig. 1). The well is in the Central Region of the larger study of temporal changes in As concentration, as described in Erickson et al. (2018, 2019b). The Central Region is composed of a complex distribution and layering of glacial sediment (Lusardi et al., 2011), with drinking water aquifers composed of sand and gravel embedded in glacial till confining units. Till layers extend laterally over large areas, and meltwater-deposited sand and gravel were created at lower drainage elevations (Knaeble, 2013; Lusardi and Jennings, 2009; Lusardi and Lively, 2009). The clay-rich till forms confining layers over the aquifers. The majority of glacial sediment deposited by meltwater consists of poorly sorted pebbles, cobbles, limestone fragments, clay, sand, and gravel (Clayton and Moran, 1982; Lusardi and Jennings, 2009; Lusardi and Lively, 2009). Nicholas et al. (2017) reported concentrations of As, iron, and sulfur (As, 2.6-12.3 mg/kg; iron, 0.89-3.61 wt\%; sulfur, 0.05-1.81 wt\%; iron/sulfur, 2-30) for till and aquifer sediments in geologic units that range across the area (Johnson et al., 2016). Other analyses of regionally extensive till and aquifer sediment find similar As, Fe, and S concentrations (Erickson and Woodruff, 2020; Thorleifson et al., 2019). The study well is in a glacial aquifer.

\section{Methods}

\subsection{Well drilling}

The study well was drilled in Hennepin County, Minnesota, in June 2014 by a licensed water well contractor in a manner typical for domestic wells in glacial aquifers in Minnesota. The 4-inch $(10 \mathrm{~cm})$ diameter well was installed using mud-rotary drilling, which includes mixing oxygenated tap water with drill cuttings to create mud that can be pumped from the drill hole. The well was completed with an 8-foot $(2.5 \mathrm{~m}), 12$-slot stainless steel screen set at a bottom depth of 222 feet $(67.5 \mathrm{~m})$ below ground surface. The annular space was grouted with bentonite, and the well was developed by pumping water from the well at a high flow rate until the discharge water was visibly clear of fine sediment. The well had a final production volume of 30 gallons/minute (113.5 liters/minute). As required by rule, the well was disinfected after well development (State of Minnesota, 2008) using the driller's standard practice of putting approximately two cups ( $380 \mathrm{~g}$, or $\approx 0.5$ liter) of calcium hypochlorite pellets into the well. A submersible pump was installed in the well 140 feet $(42.5 \mathrm{~m})$ below ground surface, and 30 feet $(9 \mathrm{~m})$ below the static water level in the well.

The drilling contractor noted nothing unusual about the well installation or well development. The well was not pumped to dryness during development. With the exception of the Minnesota Department of Health (MDH) staff member noting a chlorine smell early in the well purging process associated with sample collection 3 weeks after well construction, neither the contractor nor the MDH staff noted anything unusual about the apparent water quality when collecting the required regulatory samples or study samples (R. Torgerson, well driller, and E. Berquist, MDH hydrologist, oral communication, December 2017). The well $\log$ for the study well is provided in Supporting Information Fig. SI1. 


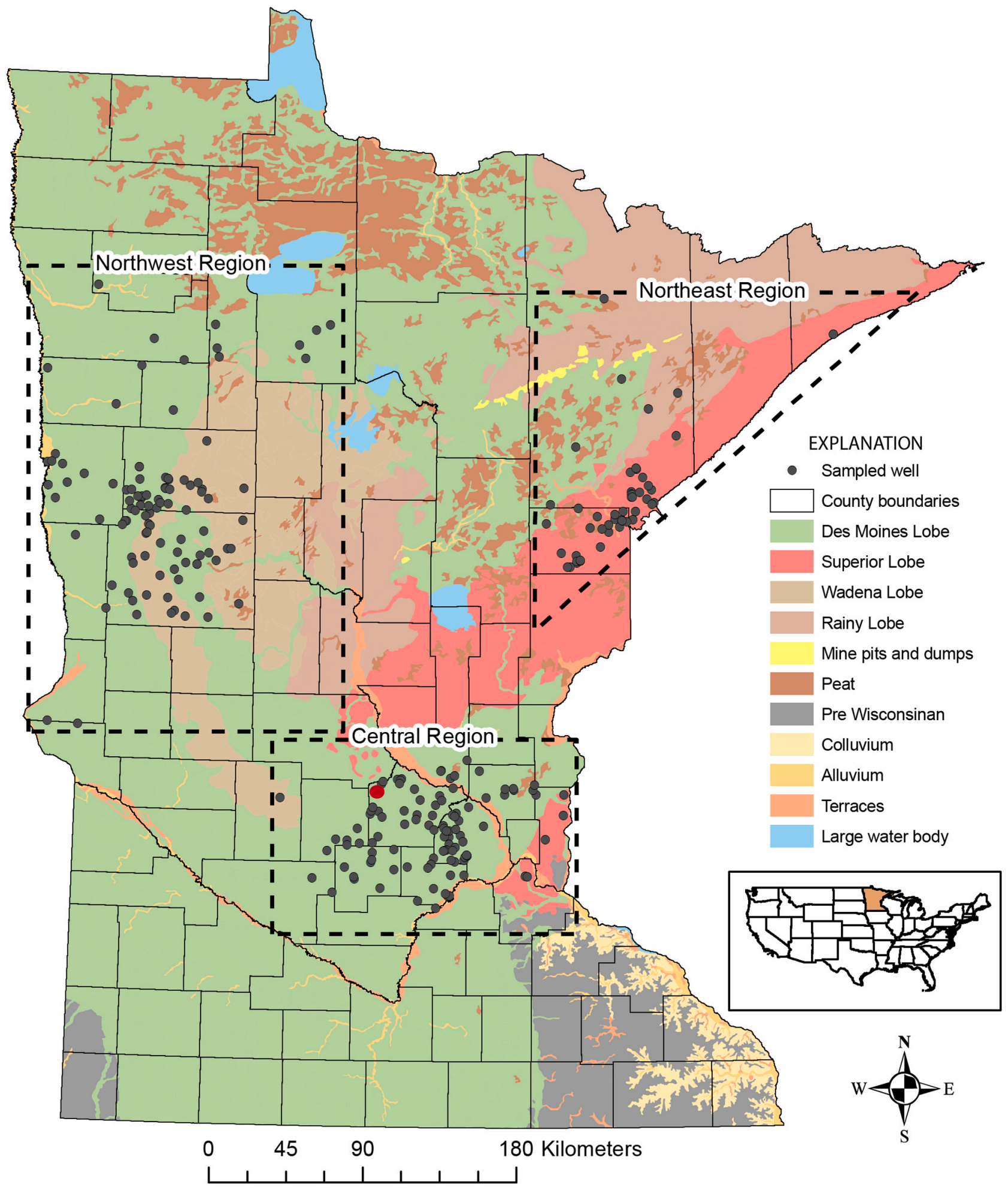

Fig. 1. Study well location (red marker) and simplified surficial geology, with the other $\approx 250$ newly constructed domestic wells sampled for larger, regional study. (For interpretation of the references to color in this figure legend, the reader is referred to the web version of this article.) Modified from Erickson et al. (2018).

\subsection{Sample collection and laboratory analysis}

The study well was sampled as part of a larger temporal water quality study (Erickson et al., 2018, 2019b). In summary, from 2014 to 2016, 254 new domestic residential water wells were sampled three times (for a total of $\sim 750$ sampling events) by MDH staff members: Round 1, within 4 weeks of well construction; Round 2, 3-6 months after initial sample collection; and Round 3,12+ months after initial sample collection. Sample collection protocols are described in previous publications (Erickson et al., 2018, 2019b) and are excerpted in the Supporting Information. During each sampling round, field measurements of physicochemical properties (specific conductance, $\mathrm{pH}$, dissolved 
oxygen $\left(\mathrm{O}_{2}\right)$, redox potential (ORP), and water temperature) were monitored to determine stability (Table 1 ). The field measurements were made with a probe attached to a multi-parameter water quality meter in a flow-through cell that isolates the groundwater from the atmosphere. Round 1 samples also had an associated driller-collected regulatory sample, which often (but not always) coincided with the Round 1 sample collection. Driller-collected regulatory samples were analyzed at a certified commercial analytical laboratory and reported to MDH as required by rule (State of Minnesota, 2017). See the Supporting Information for more detail.

The driller's regulatory sample was collected from the study well the day that the well was drilled using the drill rig pump shortly after well development. The Round 1 study sample was collected approximately 3 weeks later. All study well samples, except the driller-collected sample, were collected from an untreated, outdoor faucet. Sample dates are provided in Table 1.

Analytes included total As, aqueous As, aqueous iron, aqueous manganese, aqueous nitrate+nitrite, and sulfate. All samples except total As and sulfate were field-filtered through a 0.45 -micron filter. Samples collected for As and other metals were field-preserved with nitric acid. The aqueous nitrate+nitrite samples were field-preserved with sulfuric acid, and the sulfate samples were not preserved. All samples were immediately put in coolers with ice or refrigerated at $4{ }^{\circ} \mathrm{C}$ until delivery to the laboratory.

The groundwater samples were analyzed at the Minnesota Department of Health (MDH) Public Health Laboratory in St. Paul, Minnesota, using the following standard methods: total As, aqueous As and aqueous manganese, USEPA 200.8 (U.S. Environmental Protection Agency, 1994); aqueous iron, USEPA 200.7 (U.S. Environmental Protection Agency, 2001); sulfate, USEPA 300.1 (U.S. Environmental Protection Agency, 1997); nitrate+nitrite, standard method (SM) SM 4500-NO3 F (Standard Methods Online, 2000). Quality assurance results for blank and replicate samples are provided elsewhere (Erickson et al., 2018, 2019b).

\section{Table 1}

Water quality measurements at a central Minnesota, United States, drinking water well [-, no data; ORP, oxidation reduction potential measurement with silver/silver chloride probe; $\mathrm{mV}$, millivolts; $\mathrm{O}_{2}$, dissolved oxygen; $\mathrm{mg} / \mathrm{L}$, milligrams per liter; $\mu \mathrm{S} / \mathrm{cm}$, microsiemens per centimeter at 25 degrees Celsius; $\mu \mathrm{g} / \mathrm{L}$, micrograms per liter].

\begin{tabular}{|c|c|c|c|c|c|}
\hline \multirow[t]{2}{*}{ Analyte } & \multirow{2}{*}{$\begin{array}{l}\text { Unit of } \\
\text { measure }\end{array}$} & \multicolumn{4}{|c|}{ Sample date } \\
\hline & & $\begin{array}{l}\text { Installation } \\
6 / 23 / 2014^{\mathrm{a}}\end{array}$ & $\begin{array}{c}\text { Round } 1 \\
7 / 16 / \\
2014^{\mathrm{b}}\end{array}$ & $\begin{array}{c}\text { Round } 2 \\
10 / 28 / \\
2014^{b}\end{array}$ & $\begin{array}{c}\text { Round } 3 \\
10 / 2 / \\
2015^{\mathrm{b}}\end{array}$ \\
\hline $\mathrm{pH}$ & $\begin{array}{l}\text { standard } \\
\mathrm{pH} \text { units }\end{array}$ & - & 3.01 & 7.05 & 7.54 \\
\hline ORP & $\mathrm{mV}$ & - & 258.2 & -55.7 & -89.3 \\
\hline $\mathrm{O}_{2}$ & $\mathrm{mg} / \mathrm{L}$ & - & 4.61 & 0.65 & 0.65 \\
\hline $\begin{array}{l}\text { Specific } \\
\text { conductance }\end{array}$ & $\mu \mathrm{S} / \mathrm{cm}$ & - & 729 & 781 & 779 \\
\hline Temperature & $\begin{array}{l}\text { degrees } \\
\text { Celsius }\end{array}$ & - & 10.32 & 10.71 & 10.6 \\
\hline Total arsenic & $\mu \mathrm{g} / \mathrm{L}$ & 1550 & 1410 & 24.2 & 5.37 \\
\hline $\begin{array}{l}\text { Aqueous } \\
\text { arsenic }\end{array}$ & $\mu \mathrm{g} / \mathrm{L}$ & - & 1340 & 24.5 & 5.24 \\
\hline Nitrate + nitrite & $\begin{array}{l}\mathrm{mg} / \mathrm{L} \\
\text { nitrogen }\end{array}$ & - & $<0.05$ & $<0.05$ & $<0.05$ \\
\hline Aqueous iron & $\mathrm{mg} / \mathrm{L}$ & - & 0.229 & 0.950 & 0.857 \\
\hline Total sulfate & $\mathrm{mg} / \mathrm{L}$ & - & 26.4 & 17.8 & 15.1 \\
\hline $\begin{array}{l}\text { Aqueous } \\
\text { manganese }\end{array}$ & $\mu \mathrm{g} / \mathrm{L}$ & - & 91.1 & 76.3 & 66.2 \\
\hline
\end{tabular}

a Driller-collected regulatory sample analyzed at a certified laboratory.

b MDH hydrologist-collected samples analyzed at Minnesota Department of Health Public Health Laboratory

\subsection{Geochemical modeling}

Geochemical modeling was used to test three hypotheses about the origin of the high As (e.g., sulfides vs (oxy)hydroxides) in the study well and its mobilization mechanism: (1) arsenic originates in sulfide minerals that oxidatively dissolve due to the addition of $\mathrm{O}_{2}$ from the well installation process (simulation 2 in Table 2), (2) arsenic originates in sulfide minerals that oxidatively dissolve due to the addition of hypochlorite/hypochlorous acid $\left(\mathrm{ClO}^{-} / \mathrm{HClO}\right)$ disinfectant (simulations 3 and 4 in Table 2), and (3) arsenic originates in (oxyhydr)oxides that dissolve due to low $\mathrm{pH}$ generated by oxidative dissolution of sulfide minerals either by $\mathrm{O}_{2}$ (simulation 5 in Table 2) or $\mathrm{ClO}^{-} / \mathrm{HClO}$ (simulation 6 in Table 2). Simulation 1 represents equilibrium conditions.

To assess the reactions causing the very high concentration of aqueous As, simulations were run in the React module of the Geochemist's Workbench v.14 (Rockware Inc., 2019). The React module simulates chemical reactions to achieve thermodynamic equilibrium in systems with user-defined input solutions and/or solids. Reactions can proceed to equilibirum or at specified reaction rates. Reaction products and reactants are measured in terms of reaction progress, a dimensionless term which ranges from 0 at the beginning of the reaction to 1 at the end of the reaction. React was used to perform batch reactor-type equilibrium models due to lack of information about flow during and after pumping. This is a limitation to these models, but estimated flow parameters would likely introduce more error than they would resolve. Thus, a batch reactor-type equilibrium model was deemed most appropriate to test the validity of the three hypotheses.

The thermo.com.v8. R6 + database, and the FeOH.dat sorbing surfaces database (Rockware Inc., 2019) that describes surface complexation on $\mathrm{FeOOH}$ or $\mathrm{Fe}(\mathrm{OH})_{3}$ (Dzombak and Morel, 1990), termed HFO in the model, were used. Manual modifications (renaming of species, minerals, etc.) were made to $\mathrm{FeOH} . d a t$ for compatibility with thermo. com.v8. R6 +. The original basis fluid was based on 'Round 3' sampling results (Table 1), which we assumed was reflective of background geochemistry. Major ions (i.e., $\mathrm{Ca}^{2+}, \mathrm{Mg}^{2+}, \mathrm{HCO}_{3}^{-}$) not analyzed were estimated from the Hennepin County Geological Atlas (Balaban, 1989) and added to the basis fluid: $10 \mathrm{mg} / \mathrm{L} \mathrm{Na}^{+}, 80 \mathrm{mg} / \mathrm{L} \mathrm{Ca}^{2+}, 30 \mathrm{mg} / \mathrm{L}$ $\mathrm{Mg}^{2+}, 3 \mathrm{mg} / \mathrm{L} \mathrm{Cl}^{-}$, and $400 \mathrm{mg} / \mathrm{L} \mathrm{HCO}_{3}^{-}$(the most abundant ion, $\mathrm{HCO}_{3}^{-}$, was allowed to balance charge). Table 2 presents the basis fluid, minerals, and well-drilling induced oxidizing conditions tested in six modeling simulations. Mineral compositions used in the simulations were determined based on geochemistry from samples SC2-205ac, SC2-205c, and SC2-205bc sediment cores, described in Erickson and Woodruff (2020), assuming that all of the $S$ was pyrite and that all of the carbonate was calcite. Based on the sequential chemical extractions from Nicholas et al. (2017), core locations illustrated in Erickson and Woodruff, (2020), we apportioned $30 \%$ of the total molal concentration $\left(\mathrm{mol} / \mathrm{kg}\right.$ ) of $\mathrm{Fe}$ to $\mathrm{FeOOH}$ or $\mathrm{Fe}(\mathrm{OH})_{3}$ and $50 \%$ of the total molal concentration of As to arsenopyrite. Because $\mathrm{Ca}(\mathrm{ClO})_{2}$ was not in the thermodynamic database, hypochlorous acid $(\mathrm{HClO})$ was used instead. The $\mathrm{HClO}$ concentration was calculated based on the volume of the well to the water table $(40 \mathrm{~L})$, the $380 \mathrm{~g}(0.5$ liter $)$ of $\mathrm{Ca}(\mathrm{ClO})_{2}$ pellets added by the driller, and the assumption that $\mathrm{Ca}(\mathrm{ClO})_{2}$ would completely dissociate. Because thermodynamic data were not available for arsenopyrite or $\mathrm{HClO}$ at $10{ }^{\circ} \mathrm{C}$, the temperature of the wells, all simulations were at $25{ }^{\circ} \mathrm{C}$. Model input reactants and concentrations are summarized in Table 2. Output files from model simulations are provided in text files included in the Supporting Information; model input information is also summarized in the output text files. 
Table 2

The Geochemist's Workbench (Rockware Inc., 2019) model scenarios.

\begin{tabular}{|c|c|c|c|c|c|c|c|c|c|c|c|c|c|c|c|}
\hline \multirow[b]{2}{*}{$\begin{array}{l}\text { Model } \\
\text { simulation }\end{array}$} & \multicolumn{15}{|c|}{ Model Input Reactants } \\
\hline & $\begin{array}{c}\mathrm{FeS}_{2} \\
(\mathrm{mg} / \\
\mathrm{kg})\end{array}$ & $\begin{array}{c}\text { FeAsS } \\
(\mathrm{mg} / \\
\mathrm{kg})\end{array}$ & $\begin{array}{c}\mathrm{FeOOH} \\
(\mathrm{mg} / \mathrm{kg})\end{array}$ & $\begin{array}{c}\mathrm{Fe} \\
(\mathrm{OH})_{3} \\
\mathrm{mg} / \mathrm{kg})\end{array}$ & $\begin{array}{l}\mathrm{CaCO}_{3} \\
(\mathrm{~g} / \mathrm{kg})\end{array}$ & $\begin{array}{c}\mathrm{Mg}^{2+} \\
(\mathrm{mg} / \\
\mathrm{L})\end{array}$ & $\begin{array}{l}\mathrm{Ca}^{2+} \\
(\mathrm{mg} / \\
\mathrm{L})\end{array}$ & $\begin{array}{c}\mathrm{Fe}^{2+} \\
(\mathrm{mg} / \\
\mathrm{L})\end{array}$ & $\begin{array}{c}\mathrm{Na}^{+} \\
(\mathrm{mg} / \\
\mathrm{L})\end{array}$ & $\begin{array}{l}\mathrm{SO}_{4}^{2-} \\
(\mathrm{mg} / \\
\mathrm{L})\end{array}$ & $\begin{array}{c}\mathrm{Cl}^{-} \\
(\mathrm{mg} / \\
\mathrm{L})\end{array}$ & $\begin{array}{l}\mathrm{HCO}_{3}^{-\mathrm{b}} \\
(\mathrm{mg} / \mathrm{L})\end{array}$ & $\begin{array}{l}\mathrm{H}_{2} \mathrm{AsO}_{4}^{-} \\
(\mathrm{mg} / \mathrm{L})\end{array}$ & $\begin{array}{c}\mathrm{O}_{2} \\
\text { (aq) } \\
(\mathrm{mg} / \\
\mathrm{L})\end{array}$ & $\begin{array}{c}\mathrm{HClO} \\
(\mathrm{M})\end{array}$ \\
\hline 1. Low $\mathrm{O}_{2}$ & 5614 & 4.64 & $3900^{\mathrm{a}}$ & a & 71.7 & 30 & 80 & 0.857 & 10 & 15.1 & 3 & 400 & 0.00524 & 0.65 & 0 \\
\hline 2. High $\mathrm{O}_{2}$ & 5614 & 4.64 & $3900^{\mathrm{a}}$ & a & 71.7 & 30 & 80 & 0.857 & 10 & 15.1 & 3 & 400 & 0.00524 & 4.61 & 0 \\
\hline $\begin{array}{l}\text { 3. } \mathrm{HOCl}+\text { Low } \\
\mathrm{O}_{2}\end{array}$ & 5614 & 4.64 & $3900^{\mathrm{a}}$ & a & 71.7 & 30 & 80 & 0.857 & 10 & 15.1 & 3 & 400 & 0.00524 & 0.65 & 0.13 \\
\hline $\begin{array}{l}\text { 4. } \mathrm{HOCl}+\mathrm{High} \\
\mathrm{O}_{2}\end{array}$ & 5614 & 4.64 & $3900^{\mathrm{a}}$ & a & 71.7 & 30 & 80 & 0.857 & 10 & 15.1 & 3 & 400 & 0.00524 & 4.61 & 0.13 \\
\hline $\begin{array}{l}\text { 5. No As- } \\
\text { sulfides; high } \\
\mathrm{O}_{2}\end{array}$ & 5614 & 0 & 0 & 3900 & 6 & 30 & 80 & 0.857 & 10 & 15.1 & 3 & 400 & 0.00524 & 4.61 & 0 \\
\hline $\begin{array}{l}\text { 6. No As- } \\
\text { sulfides; high } \\
\mathrm{O}_{2}+\mathrm{HClO}\end{array}$ & 5614 & 0 & 0 & 3900 & 6 & 30 & 80 & 0.857 & 10 & 15.1 & 3 & 400 & 0.00524 & 4.61 & 0.13 \\
\hline
\end{tabular}

a simulations also run with $\mathrm{Fe}(\mathrm{OH})_{3}$ in place of $\mathrm{FeOOH}$.

b species used for charge balance.

\section{Results and discussion}

\subsection{Measured groundwater geochemistry}

The geochemical results for the study well are presented in Table 1; results for larger set of studied wells in the region were presented in Erickson et al. (2019b); data available online in Krall et al. (2018).

The study well initially had total and aqueous groundwater As concentration measurements that were extremely high, more than $1300 \mu \mathrm{g} /$ L (driller-collected regulatory sample and Round 1 sample, Table 1). Typical Round 1 As concentrations measured in well water in the Central region ranged from less than 1 to $50 \mu \mathrm{g} / \mathrm{L}$ (Figs. 2, SI-2). The Round 1 measurements of $\mathrm{O}_{2}(4.61 \mathrm{mg} / \mathrm{L})$ and ORP $(258 \mathrm{mV})$ both indicated oxic conditions. Although many wells had oxic $\mathrm{O}_{2}$ and ORP measurements during Round 1 , the study well measurements were higher than typical in other wells in the region (median $\mathrm{O}_{2} 2 \mathrm{mg} / \mathrm{L}$; median ORP $110 \mathrm{mV}$, Fig. SI-2). The measured $\mathrm{pH}$ (3.01) was low compared to the typical circumneutral $\mathrm{pH}$ in the region (median $\mathrm{pH}$ 7.1). The Round 1 concentrations were in the typical ranges for iron (median $100 \mu \mathrm{g} / \mathrm{L}$ ), manganese (median $190 \mu \mathrm{g} / \mathrm{L}$ ), and sulfate (median $26 \mathrm{mg} / \mathrm{L}$ ) (Fig. SI-2, and Krall et al., 2018).

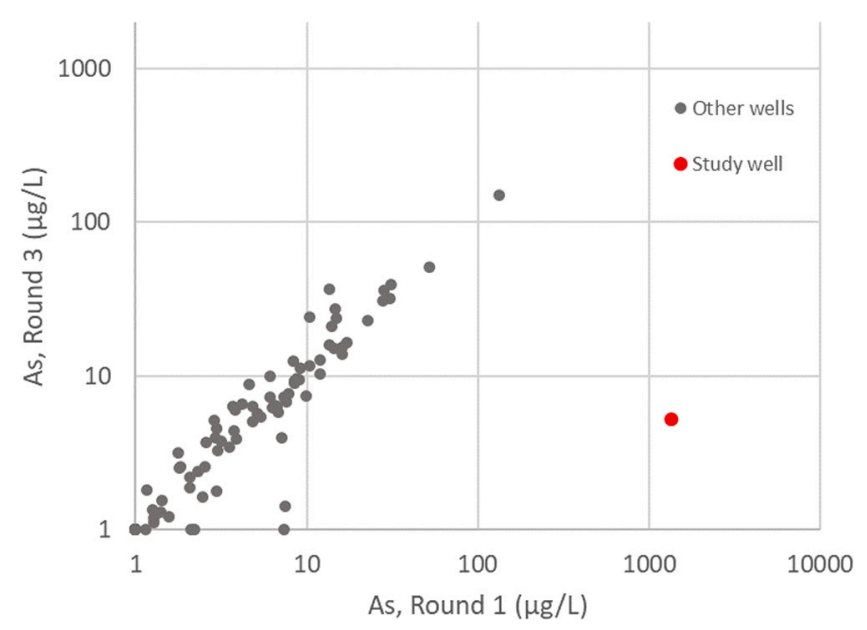

Fig. 2. Aqueous As measurements in Central Region study wells. Excluding the study well (red) there is a small but statistically significant increase in measured As concentration from Round 1 to Round 3 (Erickson et al., 2019b). Data available online (Krall et al., 2018). (For interpretation of the references to color in this figure legend, the reader is referred to the web version of this article.)
The geochemistry of the study well was markedly different 4 months after well drilling (Round 2 sampling). The total and aqueous concentration of As was approximately $25 \mu \mathrm{g} / \mathrm{L}$, a decrease of almost 50 -fold. The measurements of $\mathrm{O}_{2}$ and ORP both decreased substantially (Table 1). The measured $\mathrm{pH}$ increased to circumneutral (median $\mathrm{pH}$ for the Central Region, Fig. SI-2). The concentration of iron increased and was near the median value for other wells in the region. Manganese and sulfate decreased, with these results lower than the median for the region during Round 2 (median Mn $190 \mu \mathrm{g} / \mathrm{L}$; median sulfate $24 \mathrm{mg} / \mathrm{L}$, Fig. SI-2). Geochemical results indicated reduced but not anoxic conditions $\left(\mathrm{O}_{2}>0.5 \mathrm{mg} / \mathrm{L}\right.$ with iron $\left.>100 \mu \mathrm{g} / \mathrm{L}\right)$. These reduced but not anoxic conditions were described as 'mixed redox conditions' in Erickson et al. (2019a), and mixed redox conditions were typical of other wells in the Central Region during Round 2 sampling.

Round 3 sample results (samples collected approximately 15 months after well drilling) again showed a notable change in well water geochemistry. The concentration of aqueous As was $5.24 \mu \mathrm{g} / \mathrm{L}$, a 5-fold decrease from Round 2 - and a more than 250-times decrease from the Round 1 As sample result. The measurements of $\mathrm{O}_{2}, \mathrm{ORP}$, and iron continued to indicate mixed redox conditions, which was typical of other wells in the region during Round 3 sampling (Erickson et al., 2019a; Figs. 2, SI-2). The measured pH increased but remained circumneutral, and the concentrations of iron, manganese, and sulfate were similar to concentrations measured during Round 2.

\subsection{Simulated groundwater geochemistry}

We evaluated mechanisms to explain the high As in the study well: oxidation of As-sulfides as a result of oxidizing conditions introduced into the well and aquifer (e.g., $\mathrm{O}_{2}$ or $\mathrm{HClO}$ ), and dissolution or desorption of As from Fe (oxyhydr)oxides due to $\mathrm{pH}$ changes. Geochemical modeling results are presented in Table 3, Figs. 3 and SI-3.

\subsubsection{Mechanisms for As release}

For As to be sourced from oxidation of sulfides, As-bearing sulfides need to be present in aquifer materials. Nicholas et al. (2017) detected orpiment- and arsenopyrite-type sulfides throughout Des Moines lobe till in about equal quantities to As associated with Fe (oxyhydr)oxides, and Erickson (2005) reported observable pyrite nodules in Des Moines lobe till and sand. Geochemical analyses and sequential extractions of numerous samples from Des Moines lobe till and aquifer sands show that As, Fe, and $S$ are ubiquitous at concentrations consistent with our geochemical modeling input (Erickson and Woodruff, 2020; Thorleifson et al., 2019).

When introduced into the well, $\mathrm{Ca}(\mathrm{ClO})_{2}$ tablets rapidly dissociate 
Table 3

Results of geochemical equilibrium modeling.

\begin{tabular}{|c|c|c|c|c|c|}
\hline Model simulation $^{\mathrm{a}}$ & Aqueous Fe (mg/L) & Total SO4 (mg/L) & Aqueous As $(\mu \mathrm{g} / \mathrm{L})$ & Sorbed As ${ }^{\mathrm{b}}(\mu \mathrm{g} / \mathbf{k g})$ & pH (std units) \\
\hline 1. Low $\mathrm{O}_{2}(0.65 \mathrm{mg} / \mathrm{L})$ & 2.4 & 4.0 & 2.7 & 2135.5 & 7.0 \\
\hline 2. High $\mathrm{O}_{2}(4.61 \mathrm{mg} / \mathrm{L})$ & 2.3 & 5.9 & 2.8 & 2135.5 & 7.0 \\
\hline 3. $\mathrm{HOCl}+$ Low $\mathrm{O}_{2}$ & 103.0 & 965.0 & 2137.5 & - & 5.5 \\
\hline 4. $\mathrm{HOCl}+\mathrm{High} \mathrm{O}_{2}$ & 60.8 & 982.6 & 1923.9 & - & 5.6 \\
\hline 5. No As-sulfides; high $\mathrm{O}_{2}$ & 3.0 & 3.0 & 2.6 & 1667 & 7.0 \\
\hline 6. No As-sulfides; high $\mathrm{O}_{2}+\mathrm{HClO}$ & 1027.0 & 1694.0 & 1377.5 & 290.7 & 3.2 \\
\hline
\end{tabular}

-Not applicable

Reaction progress, Fig. 3.

a Model simulations described in 3.3 Geochemical Modeling and Supporting Information model files

b Adsorption to Fe (oxyhydr)oxides (HFO)

(reaction 1) and hypochlorite can protonate to form hypochlorous acid (reaction 2; $\mathrm{pK}_{\mathrm{a}}=7.5$, Rockware Inc., 2019). Hypochlorous acid is a weak acid but a strong oxidizing agent.

$\mathrm{Ca}(\mathrm{ClO})_{2} \leftrightarrow \mathrm{Ca}^{2+}+2 \mathrm{ClO}^{-}$

$\mathrm{ClO}^{-}+\mathrm{H}^{+} \leftrightarrow \mathrm{HClO}$

An oxidative mechanism of As release from arsenopyrite could be accomplished using one of two oxidants: $\mathrm{O}_{2}$ (reaction 3), or hypochlorous acid formed from the dissolution of calcium hypochlorite, the disinfection chemical used in the study well (reaction 4).

$\mathrm{FeAsS}_{(s)}+3.25 \mathrm{O}_{2}+1.5 \mathrm{H}_{2} \mathrm{O} \leftrightarrow \mathrm{Fe}^{2+}+\mathrm{SO}_{4}^{2-}+\mathrm{H}^{+}+\mathrm{H}_{2} \mathrm{AsO}_{4}^{-}$

$\mathrm{FeAsS}_{(s)}+6.5 \mathrm{HClO}+1.5 \mathrm{H}_{2} \mathrm{O} \leftrightarrow \mathrm{Fe}^{2+}+\mathrm{SO}_{4}^{2-}+6.5 \mathrm{Cl}^{-}+7.5 \mathrm{H}^{+}+\mathrm{H}_{2} \mathrm{AsO}_{4}^{-}$

The reactions produce the same molar quantities of $\mathrm{Fe}^{2+}, \mathrm{SO}_{4}^{2-}$, and $\mathrm{H}_{2} \mathrm{AsO}_{4}^{-}$, but when hypochlorous acid is the oxidant, it generates much more acidity, which is consistent with the low $\mathrm{pH}$ (3.01) measured in Round 1. Reaction 4 should also generate chloride, which was not measured.

Nicholas et al. (2017) detected a comparable amount of As in glacial sediments sorbed to Fe (oxyhydroxides) as was found in sulfides, indicating a second sediment source of As. The oxidation of pyrite (reaction 5 ) would also produce acidity, which can destabilize and dissolve Fe (oxyhydr)oxides (reaction 6 ). The $\mathrm{Fe}^{2+}$ generated can also be oxidized (the reserves of reaction 6).

$\mathrm{FeS}_{2(\mathrm{~s})}+7 \mathrm{HClO}+\mathrm{H}_{2} \mathrm{O} \leftrightarrow \mathrm{Fe}^{2+}+2 \mathrm{SO}_{4}^{2-}+7 \mathrm{Cl}^{-}+9 \mathrm{H}^{+}$

$\mathrm{Fe}(\mathrm{OH})_{3(s)}+2 \mathrm{H}^{+} \leftrightarrow 2.5 \mathrm{H}_{2} \mathrm{O}+\mathrm{Fe}^{2+}+0.25 \mathrm{O}_{2}$

We can rule out that high As in Round 1 sampling could have been released by reductive dissolution of $\mathrm{Fe}$ (oxyhydr)oxides, releasing adsorbed As (Erickson and Barnes, 2005a; Erickson and Woodruff, 2020; Nicholas et al., 2017). In the absence of free hydrogen sulfide, which can act to abiotically reduce and dissolve Fe (oxyhydr)oxides (Dos Santos Afonso and Stumm, 1992), the most likely mechanism for reductive dissolution is microbial (Lovley and Phillips, 1986). The driller did not note a smell of $\mathrm{H}_{2} \mathrm{~S}$, which the human nose can detect at $5 \mu \mathrm{g} / \mathrm{L}$ (Powers, 2004), so the presence of free sulfide seems unlikely. Therefore, microbial Fe (oxyhydr)oxide reduction would be the potential pathway for reductive dissolution. This pathway, however, requires anoxic conditions and would not be expected to add sulfate to the system. This reductive pathway is not consistent with our data: $\mathrm{O}_{2}$ was $4.61 \mathrm{mg} / \mathrm{L}$, and sulfate concentrations were elevated above the well's "background concentration" as represented by Round 3 results. The reductive pathway hypothesis was therefore rejected and not simulated in model runs.

\subsubsection{Evaluating As release mechanisms}

Using geochemical equilibrium modeling, we tested the potential for reactions 3 and/or 4 to liberate As from sulfide minerals (simulations 1 4 , Tables 2 and 3 ), as well as the potential for the combination of reactions 5 and 6 to liberate As from $\mathrm{Fe}$ (oxyhydr)oxides (simulations 5, 6). To simulate reaction 3 , we reacted $4.61 \mathrm{mg} / \mathrm{L} \mathrm{O}_{2}$, the amount present in Round 1 (simulation 1 , Table 3 ). We tested reaction 4 by reacting $0.130 \mathrm{M} \mathrm{HClO}$ and the background amount of $\mathrm{O}_{2}$ present in Rounds 2 and 3, $0.65 \mathrm{mg} / \mathrm{L}$ (simulation 2). And we tested the combination of reactions 3 and 4 by reacting $0.130 \mathrm{M} \mathrm{HClO}$ with $0.65 \mathrm{mg} / \mathrm{L} \mathrm{O}_{2}$ or $4.61 \mathrm{mg} / \mathrm{L} \mathrm{O}_{2}$ (simulations 3,4 ). We also tested the combination of reactions 5 and 6 by reacting $4.61 \mathrm{mg} / \mathrm{L} \mathrm{O}_{2}$ with pyrite instead of arsenopyrite and As adsorbed to $\mathrm{HFO}$ (simulation 5), and we tested the combination reaction $0.13 \mathrm{M} \mathrm{HClO}$ with $4.61 \mathrm{mg} / \mathrm{L} \mathrm{O} \mathrm{O}_{2}$ with pyrite instead of arsenopyrite and As adsorbed to HFO (simulation 6).

Results of the simulations are provided in Table 3 and Fig. 3; additional modeling results and geochemical modeling input and output details are provided in the Supporting Information. The reported concentrations are the sum of all aqueous species containing $\mathrm{Fe}^{2+}, \mathrm{SO}_{4}^{2-}$, or As and adsorbed As species.

Geochemical modeling results indicate that arsenopyrite weathering could occur due to high $\mathrm{O}_{2}$ (simulation 2) because the total amounts of liberated As (aqueous + adsorbed) were similar in simulations $1-4$. However, the addition of $\mathrm{Ca}(\mathrm{ClO})_{2}$, here simulated with hypochlorous acid, dissolves HFO, which greatly increased the aqueous As in those simulations and in simulation 6. A combination of sulfide dissolution and HFO dissolution, each of which likely is an As-repository in the aquifer, contributed to the As spike in the study well.

The lowered $\mathrm{pH}$ in Round 1 could be the result of $\mathrm{H}^{+}$production during arsenopyrite and/or pyrite weathering. Evidence for enhanced pyrite oxidation and/or dissolution with $\mathrm{HClO}$ is indicated by the large increase in aqueous $\mathrm{Fe}$ and $\mathrm{SO}_{4}^{2-}$ relative to the $\mathrm{O}_{2}$ only simulations. The greater solubility of arsenopyrite ( $\log \mathrm{K}=-14.4$, Rockware Inc., 2019) compared to pyrite (log $\mathrm{K}=-24.6$, Rockware Inc., 2019) at $25^{\circ} \mathrm{C}$ might explain why arsenopyrite weathered completely in the $\mathrm{O}_{2}$ only simulations while pyrite did not. The much greater $\mathrm{Fe}$ and $\mathrm{SO}_{4}^{2-}$ concentrations in simulations as compared to measured concentrations in Round 1 likely also indicates a kinetic barrier to complete dissolution in the well that was not accounted for in the equilibrium simulation, a subsequent mineral precipitation not being simulated, or a smaller amount of pyrite (see Section 4.3).

The simulated aqueous As concentration was not sensitive to changing $\mathrm{O}_{2}$ (simulations 1 vs 2), but it increased dramatically in response to $\mathrm{HClO}$ additions, resulting in 1377.5-2137.5 $\mu \mathrm{g} / \mathrm{L}$ aqueous As (simulations $3,4,6$ ), with highest aqueous As in arsenopyrite/ $\mathrm{HClO} /$ low $\mathrm{O}_{2}$ simulation (simulation 3 ). Most of the As released from arsenopyrite oxidation was adsorbed to $\mathrm{HFO}$ under the $\mathrm{O}_{2}$ only simulations, but this As remained in aqueous phase in the $\mathrm{HClO}$ simulations because HFO dissolved with the lower $\mathrm{pH}$ produced in that simulation (Fig. 3). When initial As was adsorbed to HFO, weathering of pyrite by HClO (simulation 6) lowered the $\mathrm{pH}$ to 3.2 , sufficiently low to dissolve HFO and 

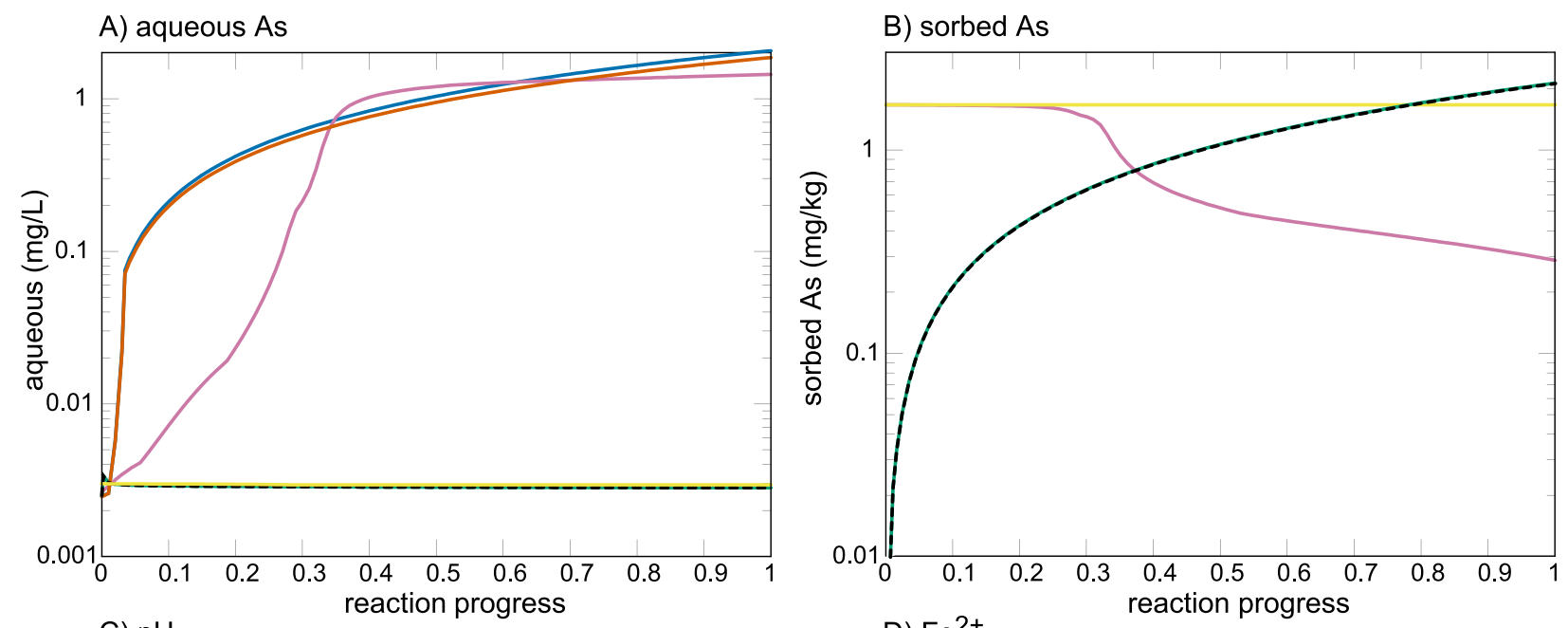

C) $\mathrm{pH}$

\section{D) $\mathrm{Fe}^{2+}$}
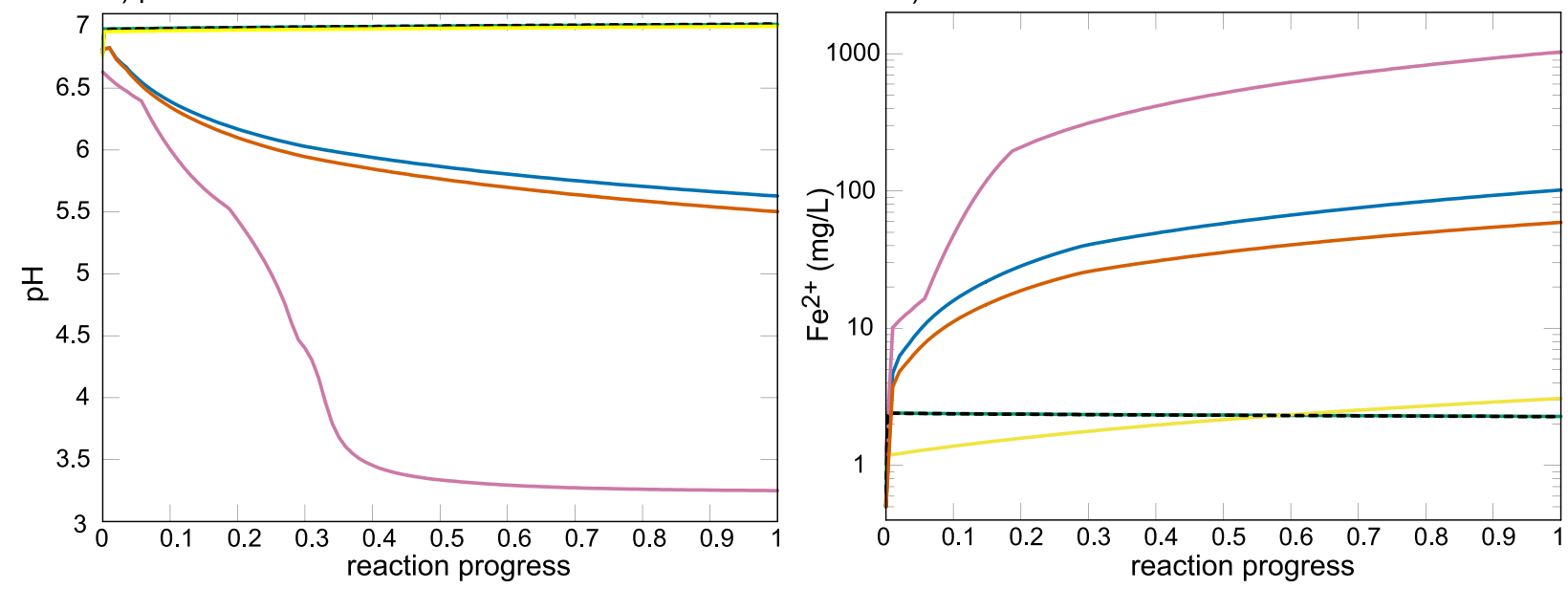

-----low $\mathrm{O}_{2}-$ high $\mathrm{O}_{2}-\operatorname{low} \mathrm{O}_{2}+\mathrm{HClO}-$ high $\mathrm{O}_{2}+\mathrm{HClO}$

no As-sulfides; high $\mathrm{O}_{2} \longrightarrow$ no As-sulfides; high $\mathrm{O}_{2}+\mathrm{HClO}$

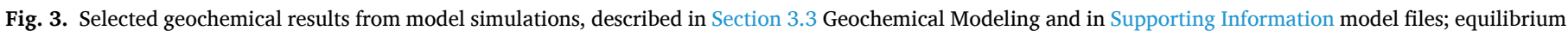

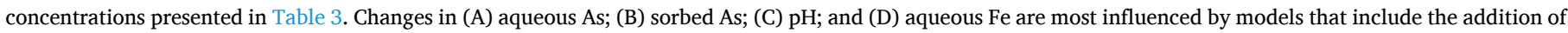

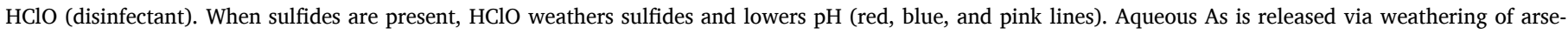

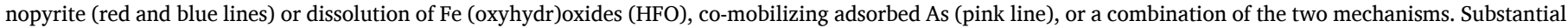

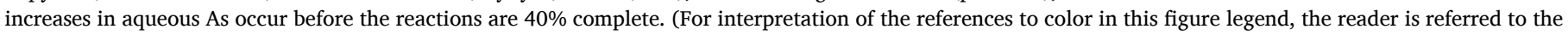
web version of this article.)

substantially increase aqueous As (As $1377.5 \mu \mathrm{g} / \mathrm{L}$ in simulation 6 vs. $2.6 \mu \mathrm{g} / \mathrm{L}$ in simulation 5 , with only $\mathrm{O}_{2}$ ). The $\mathrm{pH}$ of the simulation fluid was not substantially affected by the amount of $\mathrm{O}_{2}$ only but dropped after $\mathrm{HClO}$ addition (Fig. 3). In simulations 5 and 6 , where the calcite amount was decreased by $\sim 10 \mathrm{x}$, the $\mathrm{pH}$ conditions observed in the field were simulated, indicating either heterogeneous $\mathrm{CaCO}_{3}$ in sediments or that not all $\mathrm{CaCO}_{3}$ reacted in the timeframe of this study. The other aqueous constituents were also sensitive to HOCl: considerably higher total aqueous $\mathrm{Fe}(60.8-103.0 \mathrm{mg} / \mathrm{L})$ and $\mathrm{SO}_{4}^{2-}(965.0-982.6 \mathrm{mg} / \mathrm{L})$ was simulated with arsenopyrite weathering by $\mathrm{HClO}$ compared to the simulations of arsenopyrite weathering by only low and high $\mathrm{O}_{2}$ (2.4-4.0 mg/L for Fe; 3.0-5.9 mg/L for $\mathrm{SO}_{4}$; Table 3, Fig. 3, Supporting Information).

Because thermodynamic data were not available for $\mathrm{HClO}$ and arsenopyrite at $10^{\circ} \mathrm{C}$, a sensitivity analysis was performed for pyrite oxidation at $10{ }^{\circ} \mathrm{C}$ and $25{ }^{\circ} \mathrm{C}$ with $\mathrm{O}_{2}$ only (model run files provided in Supporting Information). The $\mathrm{pH}$ was $1.5 \%$ higher at $10^{\circ} \mathrm{C}$ than $25^{\circ} \mathrm{C}$. At high $\mathrm{O}_{2}$, the Fe relative percent difference was only $11 \%$, with the $25{ }^{\circ} \mathrm{C}$ reaction releasing more $\mathrm{Fe}$. At low $\mathrm{O}_{2}, 31 \%$ more Fe was released at $25{ }^{\circ} \mathrm{C}$. Sorbed As was similar in all simulations, and no As was released without arsenopyrite. Aqueous $\mathrm{SO}_{4}^{2-}$ was $34 \%$ higher at $10{ }^{\circ} \mathrm{C}$, but very similar between low and high $\mathrm{O}_{2}$. Aqueous Fe was much more sensitive to temperature and oxygen. These results indicate that aqueous Fe concentrations may be overestimated in the modeling compared to $10{ }^{\circ} \mathrm{C}$ for the pyrite system, while sulfate may be underestimated. However, the lack of accounting for pyrite weathering kinetics, as noted above, likely has a greater effect on the difference between measurements in Round 1 and simulations in aqueous $\mathrm{Fe}$ and $\mathrm{SO}_{4}^{2-}$. Although the sensitivity analysis could not be performed with arsenopyrite, its exothermic enthalpy for formation $\left(\Delta \mathrm{H}_{\mathrm{f}}^{0}=-42.1 \mathrm{~kJ} / \mathrm{mol}\right.$, Rockware Inc., 2019) indicates that the mineral stability is enhanced at lower temperature and suggests our simulations may overestimate the amount of As released, in accordance with the higher aqueous values in the simulations as compared to Round 1.

\subsection{Measured $v$ s. simulated groundwater geochemistry}

The model simulation results (Table 3 ) can be compared to the well water concentration measurements (Table 1) to assess potential processes responsible for the high As concentrations observed after well installation: high dissolved oxygen and/or $\mathrm{Ca}(\mathrm{ClO})_{2}$ addition. Selected measured and simulated results are presented together in Table 4. Only 
Table 4

Selected simulated and measured analyte concentrations.

\begin{tabular}{|c|c|c|c|c|c|c|c|c|}
\hline \multirow[t]{2}{*}{ Model Simulation } & \multicolumn{2}{|c|}{ Aqueous As ( $\mu \mathrm{gL})$} & \multicolumn{2}{|c|}{ Aqueous $\mathrm{Fe}(\mathrm{mg} / \mathrm{L})$} & \multicolumn{2}{|c|}{ Total $\mathrm{SO}_{4}(\mathrm{mg} / \mathrm{L})$} & \multicolumn{2}{|c|}{ pH (standard units) } \\
\hline & Simulated & Measured & Simulated & Measured & Simulated & Measured & Simulated & Measured \\
\hline 1 & 2.7 & 5.24 & 2.4 & 0.857 & 4.0 & 15.1 & 7.0 & 7.54 \\
\hline 2 & 2.8 & 1340 & 2.3 & 0.229 & 5.9 & 26.4 & 7.0 & 3.01 \\
\hline 3 & 2137.5 & 1340 & 103.0 & 0.229 & 965.0 & 26.4 & 5.5 & 3.01 \\
\hline 4 & 1923.9 & 1340 & 60.8 & 0.229 & 982.6 & 26.4 & 5.6 & 3.01 \\
\hline 5 & 2.6 & 1340 & 3.0 & 0.229 & 3.0 & 26.4 & 7.0 & 3.01 \\
\hline 6 & 1377.5 & 1340 & 1027.0 & 0.229 & 1694.0 & 26.4 & 3.2 & 3.01 \\
\hline
\end{tabular}

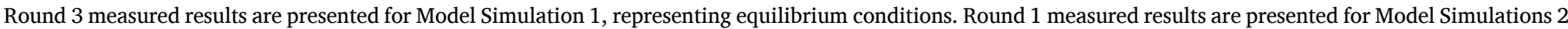
-6 , representing varying oxidizing conditions.

total As was measured on the day of drilling, the day that the $\mathrm{Ca}(\mathrm{ClO})_{2}$ was added to the well; there are no measurements of $\mathrm{pH}, \mathrm{Fe}$, or $\mathrm{SO}_{4}$ to compare to simulation results. Three weeks after well installation, however, the acidic $\mathrm{pH}$ of Round 1 water is most consistent with the results of the simulations with $\mathrm{HClO}$.

Despite being able to accurately simulate the dissolved As concentration with $\mathrm{HClO}$, our model simulations predicted substantially more dissolved $\mathrm{Fe}$ and $\mathrm{SO}_{4}$ than was observed in the study well, indicating that other secondary processes that could not be simulated were removing $\mathrm{Fe}$ and $\mathrm{SO}_{4}$ from solution. There was $11.3 \mathrm{mg} / \mathrm{L}$ more sulfate in Round 1 sampling vs. Round 3 (Tables 1 and 4). The amount of simulated $\mathrm{SO}_{4}$ rose several orders of magnitude during $\mathrm{HClO}$ simulations $(3,4$, and 6$)$ compared to $\mathrm{O}_{2}$ only simulations ( 2 and 5$)$, likely due to equilibrium dissolution of pyrite in simulations. The field measurements, however, did not match these high simulated $\mathrm{SO}_{4}$ concentrations, perhaps because the pyrite oxidation reaction may not have gone to completion in the well. This is supported by the model simulations that show substantial increases in aqueous As occur before the reactions are $40 \%$ complete (Figs. 3 and SI-3). Assuming that arsenopyrite weathered similarly regardless of $\mathrm{O}_{2}$ concentration, it is likely that the enhanced sulfate in Round 3 resulted from some additional pyrite weathering by $\mathrm{Ca}(\mathrm{ClO})_{2}$. In all simulations with $\mathrm{O}_{2}$ only (no $\mathrm{HClO}$ ), simulated aqueous Fe was $>3$ times the amount measured at any time in the well (Table 4).

We hypothesize that the precipitation of schwertmannite, which has an ideal formula $\mathrm{Fe}_{8} \mathrm{O}_{8}(\mathrm{OH})_{6} \mathrm{SO}_{4}$, could explain the disagreement between simulated and observed $\mathrm{Fe}$ and $\mathrm{SO}_{4}$ concentrations. Although not observed in our setting, schwertmannite commonly forms in oxidizing, low $\mathrm{pH}$ environments with elevated $\mathrm{Fe}$ and $\mathrm{SO}_{4}$ (Bigham et al., 1996) similar to initial conditions observed in the study well. Schwertmannite formation is currently not in the thermodynamic databases and was not considered in the models. However, based on the solubility product $\left(\mathrm{K}_{\mathrm{sp}}\right)$ of $10^{-5.28}$ reported by Yu et al. (1999), the simulated aqueous solutions would be extremely supersaturated with respect to schwertmannite (saturation index $\approx 52$ based on equilibrium $\mathrm{Fe}$ and $\mathrm{SO}_{4}$ concentrations produced in simulation 3 of $\sim 100 \mathrm{mg} / \mathrm{L}$ and $\sim 1000 \mathrm{mg} / \mathrm{L}$, respectively), indicating that schwertmannite would be expected to precipitate and lower the dissolved $\mathrm{Fe}$ and $\mathrm{SO}_{4}$, which would lead to closer agreement between our measured and simulated results. Schwertmannite is commonly associated with acid mine drainage, but it has also been found in naturally acidic environments (Schwertmann et al., 1995) and can be a precursor to other minerals (e.g., fig. 6 in Cravotta, 2008; Hammarstrom et al., 2005).

The As release in simulations 3-4 (arsenopyrite and $\mathrm{HClO}$ ) was $\approx 30 \%$ higher than measured in the well in Round 1 , and the As release in simulation 6 (pyrite, HFO and adsorbed As and $\mathrm{HClO}$ ) was about the same as measured As in Round 1. Aqueous As in simulation $1\left(\right.$ low $\mathrm{O}_{2}$ ) was lower than measured in the well in Round 3. Regardless of $\mathrm{O}_{2}$ and sulfide mineral, the simulated aqueous As concentrations were different from one another depending on whether $\mathrm{HClO}$ was present, indicating that $\mathrm{HClO}$ drives the release of As into groundwater from weathering of arsenopyrite, or weathering of pyrite, which causes the $\mathrm{pH}$-driven dissolution of As-bearing Fe (oxyhydr)oxides.
4.4. Regional-scale groundwater geochemical environment - temporal changes

The striking 300-fold decrease in As concentration in the study well over 15 months was atypical for how As concentrations changed over time in the larger set of Central Region Minnesota study wells (Figs. 1 and 2). In contrast to our study well, arsenic concentrations in other Central Region wells increased by $24 \%$ or more in $25 \%$ of the wells in the year following well installation (Erickson et al., 2019b). Most of the other geochemical changes in the study well, however, were typical for wells in the region following the installation perturbation: increase in iron concentration to presumed background levels, return to a more reducing redox condition, and return to circumneutral $\mathrm{pH}$ values (Erickson et al., 2019b). The Low $\mathrm{O}_{2}$ model (simulation 1) indicated, however, that even the mixed redox groundwater condition present in Round 3 - more than 1 year after well drilling - had substantial adsorbed As available for potential mobilization.

Eh, pH, and As concentration from the approximately 100 Central Region wells (Erickson et al., 2019b), and relevant Fe stability fields, are plotted on Fig. 4, with the study well highlighted in red. During Round 1, there was substantial scatter of As measurements within the Eh-pH space, indicating geochemical disturbance from well drilling. A year or more after well drilling, results evolve from diffuse into a vertical, semi-linear group that lies between $\mathrm{pH} 7$ and $\mathrm{pH}$ 8.5. If the Round 3 results are an indicator of common background geochemical condition, it is noteworthy that the equilibrium geochemical condition straddles the stability fields between aqueous $\mathrm{Fe}^{2+}$ and solid $\mathrm{Fe}(\mathrm{OH})_{3}$, and remains above the anoxic stability field of pyrite $(\mathrm{pH}>7)$. Results indicate that small geochemical perturbations in either Eh or $\mathrm{pH}$, which can occur from the addition of $\mathrm{Ca}(\mathrm{ClO})_{2}$ or from other reasons, could shift $\mathrm{Fe}$ between favoring solid-phase and aqueous phase, which in turn could substantially increase or decrease As concentration in well water. Resident microbial communities can potentially accelerate As release by catalyzing sulfide mineral and $\mathrm{Fe}^{2+}$ oxidation in the presence of oxygen, resulting in reactions rates that are $10^{6}$ times faster than abiotic rates (e. g. Singer and Stumm, 1970; Nordstrom, 1985; Percak-Dennett et al. 2017). Microbially mediated reactions, not considered or quantified in our study, may also influence the geochemical stability of $\mathrm{Fe}$ in the system.

Nicholas et al. (2017) found redox disequilibrium (As sulfide co-located with Fe (oxyhydr)oxides) in their samples of till and aquifer materials. Their findings indicated that incongruent oxidative weathering is one of the processes at work liberating As to waters in glacial aquifers. In theory, chemically reduced (As- and Fe-bearing sulfides) and oxidized (oxidized As and $\mathrm{Fe}$ ) redox end-members are expected to represent conditions that retain solid-phase As until the system is perturbed by changes in redox, water chemistry, or hydrologic conditions. They found the presence of As sulfide minerals with oxidized Fe, which indicate an actively weathering system with potential for As release to water. Basu and Schreiber (2013) studied arsenopyrite weathering reactions, noting the shift in As reservoir from arsenopyrite to Fe (oxyhydr)oxides after oxidative weathering of arsenopyrite. Low $\mathrm{pH}$ can also 


\section{A) Round 1}

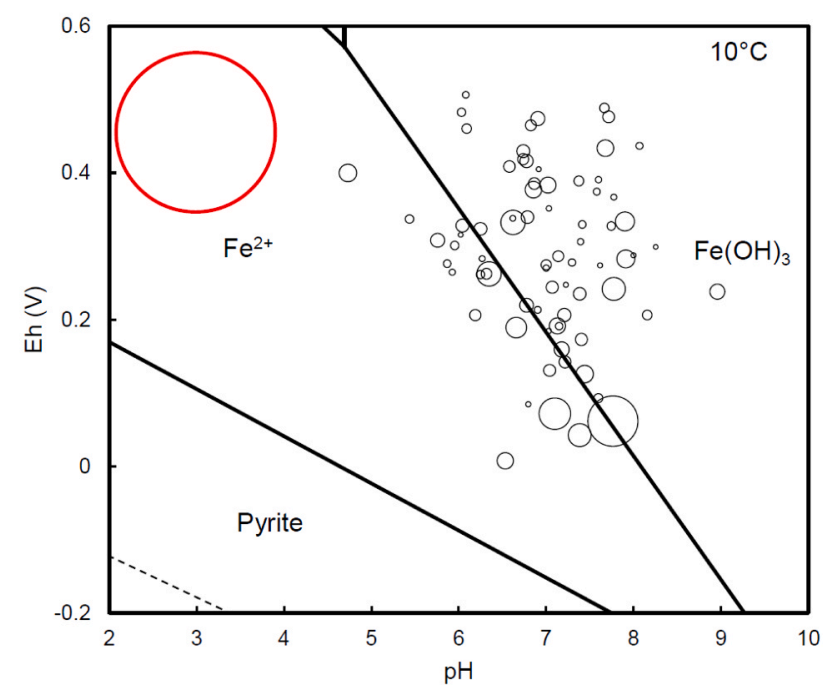

B) Round 3

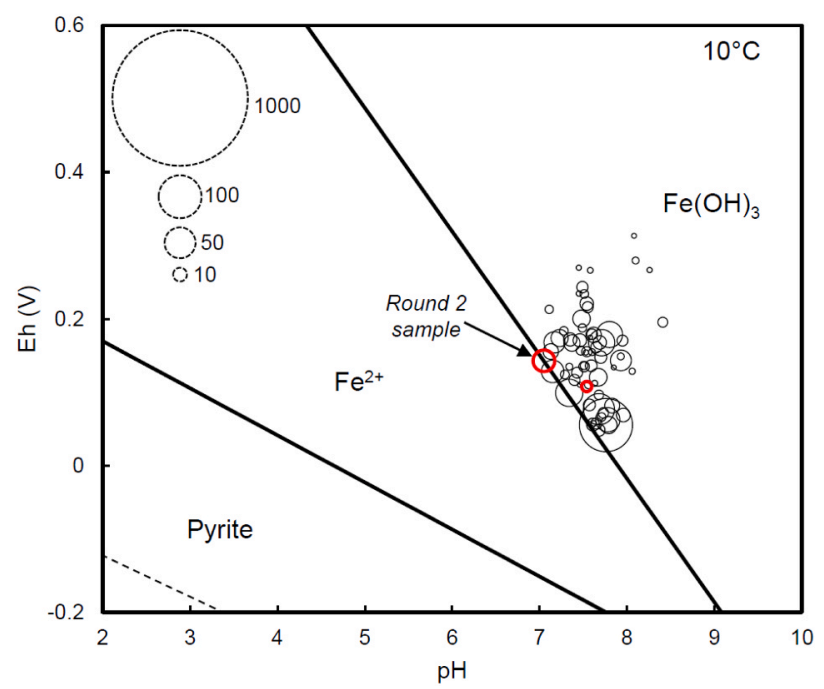

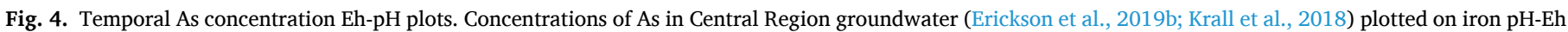

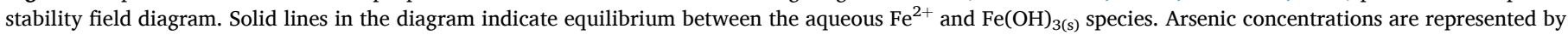

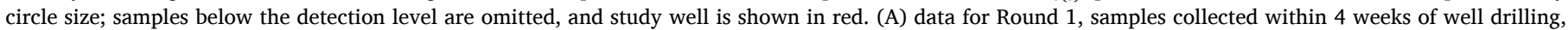

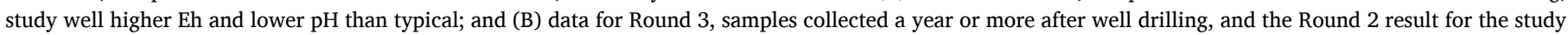

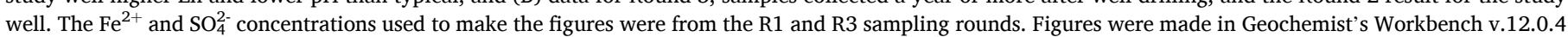

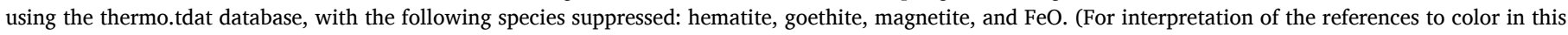
figure legend, the reader is referred to the web version of this article.)

influence As concentration, with the co-mobilization of adsorbed As if Fe (oxyhydr)oxides dissolve. The diverse As release mechanisms are consistent with our study results and the regional geographic heterogeneity of high As in well water (Fig. 4).

\subsection{Study limitations}

Our study has several limitations. The observed geochemical conditions were present in just one well, and we use the observations to illustrate that there is a potential risk of As release during routine sanitizing operations using a strongly oxidizing disinfection agent. Geochemistry not measured as part of our study were estimated for model input values. Sediment geochemistry from borings in similar materials were used to estimate sediment As, S, and Fe concentrations (Erickson and Woodruff, 2020; Thorleifson et al., 2019). Major ion groundwater geochemistry was estimated from a regional hydrogeology study (Balaban, 1989). A batch reactor-type equilibrium model was used to test hypotheses due to lack of information about flow during and after well installation because no flow parameters were measured. Simulations indicated much higher concentrations of sulfate and iron than measured in the study well. Although not observed in our study we hypothesize that schwertmannite may have sequestered the excess sulfate and iron in the initial extreme low $\mathrm{pH}$, high sulfate, high iron condition, which would have been theoretically favorable to schwertmannite formation (Cravotta, 2008).

\subsection{Public health implications and conclusions}

The geochemical measurements at our study well and the geochemical modeling results illustrate that the disturbance of well drilling and disinfection can result in short-term, very high As concentrations in wells when a low concentration of Fe sulfides are present in sediment. Studies elsewhere have demonstrated that oxidation of sulfide-containing bedrock units intersected by bedrock wells can result in very high As concentrations. To our knowledge, though, no other studies have demonstrated that an unconsolidated aquifer with low bulk As concentration and diffuse iron sulfides may be susceptible to very high concentration As release from routine well disinfection.

Well drilling introduces oxidized tap water, introduces the strong oxidizer chlorine for disinfection, disturbs aquifer materials, and induces high-flow pumping. We conclude that these well-drilling activities can oxidize arsenopyrite and/or pyrite, and the lower $\mathrm{pH}$ from the sulfide dissolution can prevent formation and/or dissolve As-containing Fe (oxyhydr)oxides. These reactions together produced the observed aqueous-phase high-As pulse of $1550 \mu \mathrm{g} / \mathrm{L}$ total As (Table 1). Geochemical modeling results are consistent with these As release mechanisms. Over the period of 15 months, a more reducing and circumneutral groundwater equilibrium is established, resulting in much lower As of $5.37 \mu \mathrm{g} / \mathrm{L}$ total As. The study well contrasts the larger regional study findings that As concentrations systematically increase in glacial wells over time (Erickson et al., 2019b).

Our study demonstrates that there is a potential risk of subsequent As release in the study region or wells in a similar geochemical setting during routine sanitizing operations using bleach or other strongly oxidizing agents. The modeling results show that a pulse-like addition of $\mathrm{O}_{2}$ from well installation was not sufficient to cause the high As release; the very high As was triggered by $\mathrm{HClO}$ reactions. Because of this potential arsenic mobilization, the Wisconsin Department of Natural Resources has recommendations for well disinfection in areas at risk for sulfide oxidation (Wisconsin Department of Natural Resources, 2012). Studies of the effect of shock chlorination on As concentrations in domestic wells, wells simulating domestic well operation, and laboratory studies of potential changes in As-containing minerals show mixed results (Gotkowitz et al., 2008; Seiler, 2006; West et al., 2012). In some wells As concentrations decrease or remain about the same, but in other wells concentrations can double; mineral repositories of As can also change.

Our study illustrates why it is crucial for public health protection that water quality sampling be conducted before a new potable well is put into service. In our study well there was no sign that the water quality 
was atypical or that the well water presented a significant health hazard to the homeowner relying on the new well as the potable domestic water supply. Our results illustrate why temporal water quality monitoring is desirable for potable wells: long-term water quality may be substantially different from initial water quality, and temporal water quality changes have public health ramifications.

Finally, our study also shows why resampling drinking water wells could be beneficial for long-term hazard mitigation. Mailloux et al. (2020) describes specific recommendations for resampling drinking water wells to minimize the hazard from As in drinking water. USEPA's Maximum Contaminant Level Goal for As concentration in drinking water is $0 \mu \mathrm{g} / \mathrm{L}$ (U.S. Environmental Protection Agency, 2018), and current advice from MDH to well owners is to consider treating drinking water if As is detected at any concentration (Minnesota Department of Health, 2019). Round 3 results (study well and 100 other Central Region wells), which are an indicator of common background geochemical condition, straddle geochemically consequential $\mathrm{Fe}$ stability fields (Fig. 4): small Eh-pH perturbations from chlorination or other factors could substantially increase or decrease As concentration in well water. Our results may have application to better understanding As mobilization processes and geochemical sensitivity in similarly geologically complex aquifers in Southeast Asia, where As can also be adsorbed to Fe (oxyhydr)oxides or can be associated with Fe sulfides (for example, Punjab Pakistan, the Bengal Basin, Huhhot Basin, Datong Basin, Mekong Delta, and Yuncheng Basin; Aziz et al., 2017; Gnanaprakasam et al., 2017; McArthur et al., 2008, 2016; Quicksall et al., 2008; Shakoor et al., 2018; Stanford et al., 2010; Stuckey et al., 2015; Wen et al., 2013). Even rare high-concentration arsenic spikes impose significant human health exposure hazards.

Our results inform strategies to reduce the hazard of As exposure through well water and therefore public-health implications. Changes in geochemical conditions relate to drinking water treatment efficacy. Changes to more reducing conditions can negatively affect home water treatment. For example, if redox is changing over time from As(V) stability to As(III) stability, and a treatment system was not designed specifically for As(III) removal, or if Fe stability also is changing to increase aqueous $\mathrm{Fe}$, then removal efficiency with typical domestic-size treatment systems may diminish. In Maine a study of common mitigation strategies for preventing As exposure found incomplete As exposure reduction; low As removal efficiency may be part of the explanation of continued As exposure (Smith et al., 2016). Another study indicates that homeowners with treatment systems may unknowingly experience lower As removal over time, particularly if changes in groundwater geochemistry are accompanied by increases in Fe, which can promote iron bacterial growth and fouling of treatment media (Spayd et al., 2015).

\section{CRediT authorship contribution statement}

Melinda L. Erickson: Conceptualization, Investigation, Visualization, Writing - original draft, Writing - review \& editing, Project administration, Funding acquisition. Elizabeth D. Swanner: Geochemical Modeling, Writing - original draft, Writing - review \& editing. Brady A. Ziegler: Geochemical Modeling, Visualization, Writing - original draft, Writing - review \& editing. Jeff R. Havig: Writing - original draft, Writing - first draft.

\section{Declaration of Competing Interest}

The authors declare that they have no known competing financial interests or personal relationships that could have appeared to influence the work reported in this paper.

\section{Acknowledgements}

Funding for this project was provided by the State of Minnesota
Clean Water Fund through the Minnesota Department of Health, USA (agreement number 19NKJFA202), and the U.S. Geological Survey Cooperative Matching Fund. We thank MDH hydrologist Emily Berquist for collecting water samples and multi-meter measurements, along with the MDH Public Health Laboratory staff for analysis of the samples. Review comments provided by Isabelle Cozzarelli (U.S. Geological Survey) and Special Issue Editor Jörg Rinklebe and anonymous reviewers (Journal of Hazardous Materials) were appreciated and greatly improved the manuscript. Any use of trade, firm, or product names is for descriptive purposes only and does not imply endorsement by the U.S. Government.

\section{Appendix A. Supporting information}

Supplementary data associated with this article can be found in the online version at doi:10.1016/j.jhazmat.2021.125409.

\section{References}

Almberg, K.S., Turyk, M.E., Jones, R.M., Rankin, K., Freels, S., Graber, J.M., Stayner, L. T., 2017. Arsenic in drinking water and adverse birth outcomes in Ohio. Environ. Res. 157 (April), 52-59. https://doi.org/10.1016/j.envres.2017.05.010.

Ayotte, J.D., Montgomery, D.L., Flanagan, S.M., Robinson, K.W., 2003. Arsenic in groundwater in Eastern New England: occurrence, controls, and human health implications. Environ. Sci. Technol. 37 (10), 2075-2083.

Ayotte, J.D., Belaval, M., Olson, S.A., Burow, K.R., Flanagan, S.M., Hinkle, S.R., Lindsey, B.D., 2015. Factors affecting temporal variability of arsenic in groundwater used for drinking water supply in the United States. Sci. Total Environ. 505, 1370-1379. https://doi.org/10.1016/j.scitotenv.2014.02.057.

Ayotte, J.D., Medalie, L., Qi, S.L., Backer, L.C., Nolan, B.T., 2017. Estimating the Higharsenic domestic-well population in the conterminous United States. Environ. Sci. Technol. https://doi.org/10.1021/acs.est.7b02881 (acs.est.7b02881).

Aziz, Z., Bostick, B.C., Zheng, Y., Huq, M.R., Rahman, M.M., Ahmed, K.M., van Geen, A., 2017. Evidence of decoupling between arsenic and phosphate in shallow groundwater of Bangladesh and potential implications. Appl. Geochem. 77, 167-177. https://doi.org/10.1016/j.apgeochem.2016.03.001.

Balaban, N.H., 1989. C-04 Geologic atlas of Hennepin County, Minnesota. Minnesota Geological Survey. Retrieved from the University of Minnesota Digital Conservancy, 〈http://hdl.handle.net/11299/58491〉.

Basu, A., Schreiber, M.E., 2013. Arsenic release from arsenopyrite weathering: Insights from sequential extraction and microscopic studies. J. Hazard. Mater. 262, 896-904. https://doi.org/10.1016/j.jhazmat.2012.12.027.

Bexfield, L.M., Jurgens, B.C., 2014. Effects of seasonal operation on the quality of water produced by public-supply wells. Groundwater 52, 10-24. https://doi.org/10.1111/ gwat. 12174.

Bigham, J.M., Schwertmann, U., Traina, S.J., Winland, R.L., Wolf, M., 1996. Schwertmannite and the chemical modeling of iron in acid sulfate waters. Geochim. Cosmochim. Acta 60 (12), 2111-2121. https://doi.org/10.1016/0016-7037(96) 00091-9.

Biswas, A., Neidhardt, H., Kundu, A.K., Halder, D., Chatterjee, D., Berner, Z., Jacks, G., Bhattacharya, P., 2014. Spatial, vertical and temporal variation of arsenic in shallow aquifers of the Bengal Basin: controlling geochemical processes. Chem. Geol. 387, 157-169. https://doi.org/10.1016/j.chemgeo.2014.08.022.

Bonsor, H.C., MacDonald, A.M., Ahmed, K.M., Burgess, W.G., Basharat, M., Calow, R.C., Dixit, A., Foster, S.S.D., Gopal, K., Lapworth, D.J., Moench, M., Mukherjee, A., Rao, M.S., Shamsudduha, M., Smith, L., Taylor, R.G., Tucker, J., van Steenbergen, F., Yadav, S.K., Zahid, A., 2017. Hydrogeological typologies of the Indo-Gangetic basin alluvial aquifer, South Asia. Hydrogeol. J. 25 (5), 1377-1406. https://doi.org/ 10.1007/s10040-017-1550-z.

Bulka, C.M., Jones, R.M., Turyk, M.E., Stayner, L.T., Argos, M., 2016. Arsenic in drinking water and prostate cancer in Illinois counties: an ecologic study. Environ. Res. 148, 450-456. https://doi.org/10.1016/j.envres.2016.04.030.

Bundschuh, J., Litter, M.I., Parvez, F., Román-Ross, G., Nicolli, H.B., Jean, J.S., Liu, C.W., López, D., Armienta, M.A., Guilherme, L.R.G., Cuevas, A.G., Cornejo, L., Cumbal, L., Toujaguez, R., 2012. One century of arsenic exposure in Latin America: a review of history and occurrence from 14 countries. Sci. Total Environ. 429, 2-35. https://doi. org/10.1016/j.scitotenv.2011.06.024.

Clayton, L., Moran, S., 1982. Chronology of the late Wisconsinan glaciation in middle North America. Quat. Sci. Rev. 1 (1), 55-82.

Cozzarelli, I.M., Schreiber, M.E., Erickson, M.L., Ziegler, B.A., 2016. Arsenic cycling in hydrocarbon plumes: secondary effects of natural attenuation. Groundwater 54 (1), 35-45. https://doi.org/10.1111/gwat.12316.

Cravotta, C.A., 2008. Dissolved metals and associated constituents in abandoned coalmine discharges, Pennsylvania, USA. Part 2: geochemical controls on constituent concentrations. Appl. Geochem. 23 (2), 203-226. https://doi.org/10.1016/j. apgeochem.2007.10.003.

Degnan, J.R., Levitt, J.P., Erickson, M.L., Jurgens, B.C., Lindsey, B.D., Ayotte, J.D., 2020. Time scales of arsenic variability and the role of high-frequency monitoring at three water-supply wells in New Hampshire, USA. Sci. Total Environ. 709, 135946 https:// doi.org/10.1016/j.scitotenv.2019.135946. 
Dos Santos Afonso, M., Stumm, W., 1992. Reductive dissolution of iron(III) (hydr)oxides by hydrogen sulfide. Langmuir 8, 1671-1675.

Dzombak, D.A., Morel, F.M.M., 1990. Surface Complexation Modeling: Hydrous Ferric Oxide. John Wiley \& Sons, New York.

Erickson, M.L., 2005. Arsenic in Upper Midwest Ground Water: Occurrence and Geochemical Mobilization Mechanisms (Ph.D. Dissertation). University of Minnesota, Minneapolis, MN.

Erickson, M.L., Barnes, R.J., 2005a. Glacial sediment causing regional-scale elevated arsenic in drinking water. Ground Water 43 (6), 796-805. https://doi.org/10.1111/ j.1745-6584.2005.00053.x.

Erickson, M.L., Barnes, R.J., 2005b. Well characteristics influencing arsenic concentrations in ground water. Water Res. 39 (16), 4029-4039. https://doi.org/ 10.1016/j.watres.2005.07.026.

Erickson, M.L., Barnes, R.J., 2006. Arsenic concentration variability in public water system wells in Minnesota, USA. Appl. Geochem. 21 (2), 305-317. https://doi.org/ 10.1016/j.apgeochem.2005.12.005.

Erickson, M.L., Woodruff, L.G., 2020. Till geochemistry from rotosonic cores in Minnesota, USA. Retrieved from https://doi.org/10.5066/P91DXODU.

Erickson, M.L., Malenda, H.F., Berquist, E.C., 2018. How or when samples are collected affects measured arsenic concentration in new drinking water wells. Groundwater 56 (6), 763-783. https://doi.org/10.1111/gwat.12643.

Erickson, M.L., Yager, R.M., Kauffman, L.J., Wilson, J.T., 2019a. Drinking water quality in the glacial aquifer system, northern USA. Sci. Total Environ. 694, 133735 https:// doi.org/10.1016/j.scitotenv.2019.133735.

Erickson, M.L., Malenda, H.F., Berquist, E.C., Ayotte, J.D., 2019b. Arsenic concentrations after drinking water well installation: time-varying effects on arsenic mobilization. Sci. Total Environ. 678, 681-691. https://doi.org/10.1016/j.scitotenv.2019.04.362.

Gnanaprakasam, E.T., Lloyd, J.R., Boothman, C., Ahmed, K.M., Choudhury, I., Bostick, B. C., van Geen, A., Mailloux, B.J., 2017. Microbial community structure and arsenic biogeochemistry in two arsenic-impacted aquifers in Bangladesh. mBio 8 (6), 1-18. https://doi.org/10.1128/mBio.01326-17.

Gotkowitz, M.B., Schreiber, M.E., Simo, J.A., 2004. Effects of water use on arsenic release to well water in a confined aquifer. Groundwater 42 (4), 568-575.

Gotkowitz, M.B., Ellickson, K., Clary, A., Bowman, G., Standridge, J., Sonzogni, W., 2008. Effect of well disinfection on arsenic in ground water. Ground Water Monit. Remediat. 28 (2), 60-67. https://doi.org/10.1111/j.1745-6592.2008.00192.x.

Hammarstrom, J.M., Brady, K.I., Cravotta, C.A., 2005. Acid-rock drainage at Skytop, Centre County, Pennsylvania, 2004. U.S. Geological Survey Open-File Report 2005-1148.

Johnson, M.D., Adams, R.S., Gowan, A.S., Harris, K.L., Hobbs, H.C., Jennings, C.E., et al., 2016. RI-68 Quaternary Lithostratigraphic Units of Minnesota. University of Minnesota Digital Conservancy. 〈http://hdl.handle.net/11299/177675〉.

Knaeble, A.R., 2013. County Atlas Series, Atlas C-30, Part A, Wright County, Plate 4-Quaternary Stratigraphy. Minneapolis, MN. https://doi.org/10.1029/2004PA00 107.

Kocar, B.D., Herbel, M.J., Tufano, K.J., Fendorf, S., 2006. Contrasting effects of dissimilatory iron(III) and arsenic(V) reduction on arsenic retention and transport. Environ. Sci. Technol. 40 (21), 6715-6721. https://doi.org/10.1021/es061540k.

Krall, A.L., Erickson, M.L., Berquist, E.C., 2018. Total and aqueous arsenic concentrations and physiochemical characteristics of groundwater from newly constructed drinking water wells in central, northwest, and northeast Minnesota, 2014 - 2016 (ver. 2.0, July 2018): U.S. Geological Survey data release. Retrieved from https://doi. org/10.5066/F7736PVK.

Lovley, D.R., Phillips, E.J.P., 1986. Organic matter mineralization with reduction of ferric iron in anaerobic sediments. Appl. Environ. Microbiol. 51, 683-689.

Lusardi, B.A., 1997. Minnesota at a glance quaternary glacial geology. https://doi. org/10.1002/esp.590.

Lusardi, B.A., Jennings, C.E., 2009. County Atlas Series, Atlas C-20 McLeod County, PART A, Plate 4-Surficial Geology. Minneapolis, MN. Retrieved from $\langle$ http://hdl. handle.net/11299/58781>.

Lusardi, B.A., Lively, R.S., 2009. County Atlas Series, Atlas C-20, McLeod County Part A, Plate 5-Quaternary Stratigraphy, and Sand Distribution Model. Minneapolis, MN. Retrieved from 〈https://conservancy.umn.edu/handle/11299/58781〉.

Lusardi, B.A., Jennings, C.E., Harris, K.L., 2011. Provenance of Des Moines lobe till records ice-stream catchment evolution during Laurentide deglaciation. Boreas 40 (4), 585-597. https://doi.org/10.1111/j.1502-3885.2011.00208.x.

Mailloux, B.J., Procopio, N.A., Bakker, M., Chen, T., Ahmed, K.M., Mozumder, M.R.H., et al., 2020. Recommended sampling intervals for arsenic in private wells. Groundwater. https://doi.org/10.1111/gwat.13020.

McArthur, J.M., Ravenscroft, P., Banerjee, D.M., Milsom, J., Hudson-Edwards, K.A., Sengupta, S., Bristow, C., Sarkar, A., Tonkin, S., Purohit, R., 2008. How paleosols influence groundwater flow and arsenic pollution: a model from the Bengal Basin and its worldwide implication. Water Resour. Res. 44 (11), 1-30. https://doi.org/ 10.1029/2007WR006552.

McArthur, J.M., Banerjee, D.M., Sengupta, S., Ravenscroft, P., Klump, S., Sarkar, A., Disch, B., Kipfer, R., 2010. Migration of As, and 3H/3He ages, in groundwater from West Bengal: implications for monitoring. Water Res. 44 (14), 4171-4185. https:// doi.org/10.1016/j.watres.2010.05.010.

McArthur, J.M., Ghosal, U., Sikdar, P.K., Ball, J.D., 2016. Arsenic in groundwater: the deep late pleistocene aquifers of the Western Bengal Basin. Environ. Sci. Technol. 50 (7), 3469-3476. https://doi.org/10.1021/acs.est.5b02477.

Minnesota Department of Health, 2017a. Drinking Water by the numbers for fiscal year 2017-2018. Retrieved from /http://www.health.state.mn.us/divs/eh/water/com/ dwar/waternumbersfy17.pdf $\rangle$.

Minnesota Department of Health, 2017b. MN public health data access. Retrieved July 17, 2017, from 〈https://apps.health.state.mn.us/mndata/webmap/wells.html〉.
Minnesota Department of Health, 2019. Arsenic in Well Water. St. Paul, Minnesota.

Monrad, M., Ersbøll, A.K., Sørensen, M., Baastrup, R., Hansen, B., Gammelmark, A. Tjønneland, A., Overvad, K., Raaschou-Nielsen, O., 2017. Low-level arsenic in drinking water and risk of incident myocardial infarction: a cohort study. Environ. Res. 154, 318-324. https://doi.org/10.1016/j.envres.2017.01.028 (July 2016).

Nicholas, S.L., Erickson, M.L., Woodruff, L.G., Knaeble, A.R., Marcus, M.A., Lynch, J.K., Toner, B.M., 2017. Solid-phase arsenic speciation in aquifer sediments: a micro-Xray absorption spectroscopy approach for quantifying trace-level speciation. Geochim. Cosmochim. Acta 211, 228-255. https://doi.org/10.1016/j. gca.2017.05.018.

Nordstrom, D.K., 1985. The rate of ferrous iron oxidation in a stream receiving acid mine effluent in Selected papers in the hydrologic sciences, U.S. Geological Survey WaterSupply Paper 2270

Percak-Dennett, E., He, S., Converse, B., Konishi, H., Xu, H., Corcoran, A., Noguera, D., Chan, C., Bhattacharyya, A., Borch, T., Boyd, E., Roden, E.E., 2017. Microbial acceleration of aerobic pyrite oxidation at circumneutral pH. Geobiology 15 (5), 690-703.

Powers, W., 2004. The Science of Smell Part 1: odor perception and physiological response. Ames, IA.

Quicksall, A.N., Bostick, B.C., Sampson, M.L., 2008. Linking organic matter deposition and iron mineral transformations to groundwater arsenic levels in the Mekong delta, Cambodia. Appl. Geochem. 23 (11), 3088-3098. https://doi.org/10.1016/j. apgeochem.2008.06.027.

Ravenscroft, P., McArthur, J.M., Hoque, M.A., 2013. Stable groundwater quality in deep aquifers of Southern Bangladesh: the case against sustainable abstraction. Sci. Total Environ. 454-455, 627-638. https://doi.org/10.1016/j.scitotenv.2013.02.071.

Rockware Inc, 2019. Geochemist's Workbench v.14, React module.

Schreiber, M.E., Rimstidt, J.D., 2013. Trace element source terms for mineral dissolution. Appl. Geochem. 37, 84-101.

Schreiber, M.E., Simo, J.A., Freiberg, P.G., 2000. Stratigraphic and geochemical controls on naturally occurring arsenic in groundwater, eastern Wisconsin, USA. Hydrogeol. J. 8 (2), 161-176. https://doi.org/10.1007/s100400050003.

Schwertmann, U., Bigham, J.M., Murad, E., 1995. The first occurrence of schwertmannite in a natural stream environment. Eur. J. Mineral. 7 (3), 547-552. https://doi.org/10.1127/ejm/7/3/0547.

Seiler, R.L., 2006. Mobilization of lead and other trace elements following shock chlorination of wells. Sci. Total Environ. 367 (2-3), 757-768. https://doi.org/ 10.1016/j.scitotenv.2006.01.020.

Shakoor, M., Niazi, N., Bibi, I., Rahman, M., Naidu, R., Dong, Z., Shahid, M., Arshad, M., 2015. Unraveling health risk and speciation of arsenic from groundwater in rural areas of Punjab, Pakistan. Int. J. Environ. Res. Public Health 12 (10), 12371-12390. https://doi.org/10.3390/ijerph121012371.

Shakoor, M.B., Bibi, I., Niazi, N.K., Shahid, M., Nawaz, M.F., Farooqi, A., Naidu, R., Rahman, M.M., Murtaza, G., Lüttge, A., 2018. The evaluation of arsenic contamination potential, speciation and hydrogeochemical behaviour in aquifers of Punjab, Pakistan. Chemosphere 199, 737-746. https://doi.org/10.1016/j. chemosphere.2018.02.002 (February).

Shankar, S., Shanker, U., Shikha, 2014. Arsenic contamination of groundwater: a review of sources, prevalence, health risks, and strategies for mitigation. Sci. World J. 18. https://doi.org/10.1155/2014/304524 (2014).

Singer, P.C., Stumm, W., 1970. Acidic mine drainage: the rate-determining step. Science 167 (3921), 1121-1123.

Smedley, P.L., Kinniburgh, D.G., 2002. A review of the source, behaviour and distribution of arsenic in natural waters. Appl. Geochem. 17 (5), 517-568. https:// doi.org/10.1016/S0883-2927(02)00018-5.

Smith, A.E., Lincoln, R.A., Paulu, C., Simones, T.L., Caldwell, K.L., Jones, R.L., Backer, L. C., 2016. Assessing arsenic exposure in households using bottled water or point-ofuse treatment systems to mitigate well water contamination. Sci. Total Environ. 544, 701-710. https://doi.org/10.1016/j.scitotenv.2015.11.136.

Spayd, S.E., Robson, M.G., Buckley, B.T., 2015. Whole-house arsenic water treatment provided more effective arsenic exposure reduction than point-of-use water treatment at New Jersey homes with arsenic in well water. Sci. Total Environ. 505, 1361-1369. https://doi.org/10.1016/j.scitotenv.2014.06.026.

Standard Methods Online, 2000. SM 4500-NO3 F 21st ED. Retrieved January 1, 2016, from $\langle\mathrm{http}: / /$ standardmethods.org $/\rangle$.

Stanford, B.D., Amoozegar, A., Weinberg, H.S., 2010. The impact of co-contaminants and septic system effluent quality on the transport of estrogens and nonylphenols through soil. Water Res. 44, 1598-1606. https://doi.org/10.1016/j. watres.2009.11.011.

State of Minnesota, 2008. Minnesota Administrative Rules, 4725.5550: Water-supply well disinfection. Retrieved from $\langle$ https://www.revisor.mn.gov/rules/4725.5550/).

State of Minnesota, 2017. Minnesota Administrative Rules, 4725.5650: Water Quality Samples From Newly Constructed Potable Water-Supply Well. Retrieved from $\langle$ https: $/ /$ www.revisor.mn.gov/rules/?id=4725.5650 $/$.

Stuckey, J.W., Schaefer, M.V., Benner, S.G., Fendorf, S., 2015. Reactivity and speciation of mineral-associated arsenic in seasonal and permanent wetlands of the Mekong Delta. Geochim. Cosmochim. Acta 171, 143-155. https://doi.org/10.1016/j. gca.2015.09.002.

Thomas, M.A., 2007. The association of arsenic with redox conditions, depth, and ground-water Aage in the glacial aquifer system of the Northern United States. U.S. Geological Survey Scientific Investigations Report 2007-5036, 25 p. Retrieved from https://doi.org/10.3133/sir20075036.

Thorleifson, L.H., Conrad, D.R., Staley, A.E., 2019. Geochemical analysis of till from Minnesota Drill Cores, Minnesota Geological Survey Open File Report OFR-19-2, 15 p., 9 digital files. https://doi.org/10.1029/91eo00083. 
Tufano, K.J., Reyes, C., Saltikov, C.W., Fendorf, S., 2008. Reductive processes controlling arsenic retention: Revealing the relative importance of iron and arsenic reduction. Environ. Sci. Technol. 42 (22), 8283-8289. https://doi.org/10.1021/es801059s.

U.S. Environmental Protection Agency, 1994. Method 200.8: Determination of Trace Elements in Waters and Wastes by Inductively Coupled Plasma-Mass Spectrometry, Revision 5.4 .

U.S. Environmental Protection Agency, 1997. Method 300.1: Determination of Inorganic Anions in Drinking Water by Ion Chromatography, Revision 1.0.

U.S. Environmental Protection Agency, 2001. Method 200.7 Trace Elements in Water, Solids, and Biosolids by Inductively Coupled Plasma-Atomic Emission Spectrometry, Revision 5.0.

U.S. Environmental Protection Agency, 2017. Drinking Water Requirements for States and Public Water Systems. Retrieved July 17, 2017, from /https://www.epa.gov/dw reginfo/chemical-contaminant-rules $\rangle$.

U.S. Environmental Protection Agency, 2018. 2018 Edition of the Drinking Water Standards and Health Advisories Tables. Retrieved from /https://www.epa.gov/ sdwa/2018-drinking-water-standards-and-advisory-tables $\rangle$.

Wallis, I., Pichler, T., 2018. Generating false negatives and false positives for As and Mo concentrations in groundwater due to well installation. Sci. Total Environ. 631-632, 723-732. https://doi.org/10.1016/j.scitotenv.2018.03.063.

Warner, K.L., Ayotte, J.D., 2014. Water quality in the glacial aquifer system, northern United States, 1993-2009. U.S. Geological Survey Circular 1352. https://doi. org/10.3133/cir1352.
Welch, A.H., Westjohn, D.B., Helsel, D.R., Wanty, R.B., 2000. Arsenic in ground water of the United States: occurrence and geochemistry. Ground Water 38 (4), 589-604. https://doi.org/10.1111/j.1745-6584.2000.tb00251.x.

Wen, D., Zhang, F., Zhang, E., Wang, C., Han, S., Zheng, Y., 2013. Arsenic, fluoride and iodine in groundwater of China. J. Geochem. Explor. 135, 1-21. https://doi.org/ 10.1016/j.gexplo.2013.10.012.

West, N., Schreiber, M., Gotkowitz, M., 2012. Arsenic release from chlorine-promoted alteration of a sulfide cement horizon: evidence from batch studies on the St. Peter Sandstone, Wisconsin, USA. Appl. Geochem. 27 (11), 2215-2224. https://doi.org/ 10.1016/j.apgeochem.2012.01.019.

Wisconsin Department of Natural Resources, 2012. Well chlorination in arsenic sensitive areas: too much of a good thing? (PUB-DG-069). Madison, WI.

World Health Organization, 2017. Arsenic. Retrieved July 17, 2017, from 〈http://www. who.int/ipcs/assessment/public_health/arsenic/en/>.

Yu, J.Y., Heo, B., Choi, I.K., Cho, J.P., Chang, H.W., 1999. Apparent solubilities of schwertmannite and ferrihydrite in natural stream waters polluted by mine drainage. Geochim. Cosmochim. Acta 63 (19-20), 3407-3416. https://doi.org/10.1016/ S0016-7037(99)00261-6.

Ziegler, B.A., McGuire, J.T., Cozzarelli, I.M., 2015. Rates of As and trace-element mobilization caused by Fe reduction in mixed BTEX-ethanol experimental plumes. Environ. Sci. Technol. 49 (22), 13179-13189. https://doi.org/10.1021/acs. est.5b02341. 